NBER WORKING PAPER SERIES

\title{
RISING BURDENS OF PROOFS AND THE GRAND BARGAIN OF WORKERS' COMPENSATION LAWS
}

\author{
Andy Yuan \\ Price V. Fishback \\ Working Paper 26980 \\ http://www.nber.org/papers/w26980 \\ NATIONAL BUREAU OF ECONOMIC RESEARCH \\ 1050 Massachusetts Avenue \\ Cambridge, MA 02138 \\ April 2020
}

Yuan: JD, PhD Candidate in Economics, University of Arizona; Fishback: Thomas R. Brown Professor of Economics, University of Arizona \& NBER. We thank seminar participants at University of Arizona and the 29th Annual Meeting of the American Law and Economics Association. The views expressed herein are those of the authors and do not necessarily reflect the views of the National Bureau of Economic Research.

At least one co-author has disclosed a financial relationship of potential relevance for this research. Further information is available online at http://www.nber.org/papers/w26980.ack

NBER working papers are circulated for discussion and comment purposes. They have not been peer-reviewed or been subject to the review by the NBER Board of Directors that accompanies official NBER publications.

(C) 2020 by Andy Yuan and Price V. Fishback. All rights reserved. Short sections of text, not to exceed two paragraphs, may be quoted without explicit permission provided that full credit, including $(\odot$ notice, is given to the source. 
Rising Burdens of Proofs and The Grand Bargain of Workers' Compensation Laws Andy Yuan and Price V. Fishback

NBER Working Paper No. 26980

April 2020

JEL No. J32,J38,K31,K4

\begin{abstract}
$\underline{\text { ABSTRACT }}$
Nearly every state has amended workers' compensation laws in the last two decades and the national averages of cash and medical benefits paid per covered worker have declined. As a result, writers have suggested that the states might be cutting back on workers' compensation benefits. We show that measures of the statutory benefits have been rising over time, a trend that work against the declining trend in average payouts per covered worker. A decline in accident rates at the national level has contributed to the decline in payouts. We then investigate the impact of specific state laws related to burdens of proof and limits on medical coverage after developing an annual panel data set for all states between 1997 and 2016. The results show that state laws that ban liberal construction of the rules and apportion benefits based on pre-existing conditions contribute to sharp declines in the states where they are enacted.
\end{abstract}

\author{
Andy Yuan \\ Economics Department \\ University of Arizona \\ Tucson, AZ 85721 \\ USA \\ andyyuan@email.arizona.edu \\ Price V. Fishback \\ Department of Economics \\ University of Arizona \\ Tucson, AZ 85721 \\ and TIAA-CREF Institute \\ and also NBER \\ pfishback@eller.arizona.edu
}




\section{Introduction}

The state workers' compensation laws have been described as a "Grand Bargain" between employers, workers, and insurers. In the early 1900s states started enacting laws in which workers gave up their rights to sue employers for negligence when injured in return for a strict liability rule in which employers compensated them for all accidents "arising out of and in the course of employment." Fishback \& Kantor (1998) found that a significant share of each set of stakeholders-employers, workers, and insurance companies-gained from the passage of the laws 1

Workers' compensation practitioners and scholars have expressed concerns that this Grand Bargain has been eroded by new state laws over the last 20 years ${ }^{2}$ Oklahoma, in particular, passed over 20 new laws between 2003 and 2013 that reduced access to benefits, culminating with an opt-out option for employers in 2013 that was declared unconstitutional by the Oklahoma Supreme Court (Spieler 2016, 948-55). The concerns received more public attention when Michael Grabell of ProPublica and Howard Berkes of NPR in March 2015 published an online article titled "The Demolition of Workers' Comp." They performed a study of new state workers' compensation laws between 2002 to 2014 and came to the conclusion that states had "slashed workers' compensation benefits," and were in a "race to the bottom."

The downward trends in Figure 1 of real national cash wage replacement payments per covered worker and real medical payments per covered worker seem consistent with this claim. However, most of the new state laws about dollar values of benefits were small changes. We construct a measure of statutory benefits for the period from state laws using methods developed by Allen (2015) and Fishback \& Kantor (1998) in Figure 2. The national average of this measure of real statutory benefits has generally risen over the period, largely because weekly maximums have been indexed to state average wages in most states since the early 1980s (Allen 2015) 3

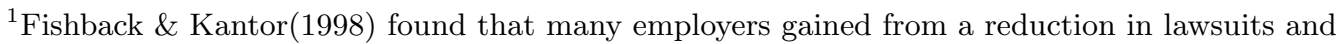
because they could pass much of the higher costs of accident payments on to nonunion workers through slower growth in wages. Many workers gained because they were better insured even if they paid part of the cost. They received payments for all accidents, and the payments were often higher than what they received under that actual operation of the negligence regime. Many insurers gained because the coverage of the entire payroll helped resolve adverse selection problems that allowed them to profitably sell more insurance, as long as there was no state monopoly on insurance. In 1996 there were 6 states with exclusive state funds and 19 with state funds that compete with private insurers.

${ }^{2}$ For example, in fall 2015 a group of leading workers' compensation scholars and practitioners met at a symposium titled "The Demise of the Grand Bargain." The Rutgers University Law Review published a series of papers and commentaries on the issue including ones by Spieler (2016), Relkin (2016), Morantz et al. (2016) and Williams (2016) that described new challenges faced by workers in obtaining benefits.

${ }^{3}$ The measure calculates expected benefits by calculating the payments for four kinds of accidents and then getting a weighted average of the benefits by multiplying by the probability of each kind 
Since the payments per covered worker in Figure 1 fell, other changes that reduced payments per worker had to have more than counteracted the rise in real statutory benefits. One change is beneficial to workers. There was a significant decline in fatal and non-fatal accident rates in the workplace. Between 1995 and 2014 the annual fatality rate per million workers fell by roughly one-third, while the workplace fatal accident rate fell by roughly 59 percent 4 Figure 3 documents the downward trend in the national workplace fatal accident rate.

The other reasons for the decline might come from legislative changes that influenced the probability of receiving any compensation and/or prevented workers from getting full statutory compensation (Spieler 2016). A Department of Labor (undated, 17) report suggested that such changes "had enormous, though perhaps more hidden, impact on injured workers' access to benefits." To our knowledge, we are one of the first to try to measure the impact of such changes. We focus on five types of laws, all of which can plausibly influence both cash benefits and medical benefits: (1) laws that prohibit the use of the liberal construction rule; (2) laws that presume intoxication was the proximate cause of injuries to an intoxicated worker; (3) laws that apportion benefits based on a workers' preexisting conditions; (4) laws establishing medical fee schedules, and (5) laws establishing stat-wide net-works of physicians to treat work-related injuries. The first three changes raise workers' burdens of proof and inevitably require workers to seek additional evidence to support their claims, which would impose additional costs on their attempts to obtain benefits or even make obtaining benefits infeasible. The last two legal changes primarily aim at reducing the medical costs. However, cash benefits might also be plausibly affected by these two changes if they lead to shorter treatment periods of work-related injuries (Bernacki et al. 2006).

To measure the impact of these laws, we develop an annual panel data set for the states between 1997 and 2016. We then estimate the relationship between benefits per covered worker and a measure of statutory benefits, fatal accident rates, and these five types of laws in a model with state and year fixed effects and statespecific time trends. The relationships are identified by deviations from trend over time within the same state while controlling for nationwide shocks to the systems, changes in statutory benefits, and changes in accident rates.

Our findings suggest that the laws prohibiting liberal construction and laws apportioning benefits based on pre-existing conditions contributed to reducing both cash benefits and medical benefits per worker covered. Benefits were also negatively related to intoxication and physician network laws, but there is evidence of negative relationships between benefits and the eventual adoption of the laws before the

of accident. See the data section below for discussions of the methods.

${ }_{4}^{4}$ Fishback (2016) calculated these estimates from data in McLaren \& Baldwin (2016). For nonfatal accidents the BLS changed its definitions and reporting in 2002. The new methods led to an accident rate measure that was about 7.5 percent lower than the old measure, so we scaled up the 2014 estimate for nonfatal accidents by that 7.5 percent before calculating the change in the rate between 1994 and 2015 . 
laws were enacted. We do not find evidence suggesting any significant impacts of establishing medical fee schedule laws on either cash or medical benefits payment per worker covered.

The remainder of the paper is organized as follows. Section II reviews relevant institutional features and the economic literature of workers' compensation programs. Section III provides detailed descriptions of each of the five types of laws we empirically examine. Section IV describes the data source. Section V presents the econometric models. Section VI and VII describe the main results and the results of placebo tests respectively. Section VIII offers concluding remarks.

\section{The Structure of Workers' Compensation}

From their beginnings workers' compensation programs have been state programs. Employers are liable for accidents to workers that "arise out of or in the course of employment." Employers cover this liability by direct purchase of insurance or by forming self-insured pools if they can document adequate resources.5 Workers' compensation benefits generally consist of two types: medical benefits and cash benefits. Medical benefits cover the entire scope of medical expenses incurred in treating work-related injuries and illnesses. Cash benefits partially compensate for lost earnings of workers related to the accident. Such benefits are available to workers who became disabled due to workplace accidents or to the dependents of deceased workers. The wage-replacement benefits typically have a duration limit and are a fraction of workers' pre-injury wages, with maximum and minimum restrictions usually tied to state average wages. Overall, the program is a multi-billion-dollar safety net program. In 2015, the total amount of workers' compensation benefits payments to non-federal employees amounted to $\$ 30$ billion for medical payment and $\$ 28$ billion for wage replacement.

Economic studies of workers' compensation focus on examining the impacts of the following three key regulations: monetary benefits, non-monetary eligibility requirements and medical-care restrictions. The main outcome variables are related to workplace safety and the program costs. The empirical strategy typically exploits the inter-state and inter-temporal variation of regulations of state workers' compensation programs.

One large strand of literature used a variety of measures of the cash benefits for wage replacement, which we refer to as "expected benefits." Allen (2015) and Fishback \& Kantor (1995) developed measures of cash benefits to examine the political

\footnotetext{
${ }^{5}$ In many states employers purchase from private insurance companies. In 2019 North Dakota, Ohio, Washington, and Wyoming operate exclusive state compensation fund, although Ohio and Washington allow self-insurance in limited cases. Some private insurance can be found in those states in cases where group policies overlap state boundaries. Another 21 states have insurance funds that compete with private insurers for workers' compensation coverage. For more see https:// www .insureon.com/insurance-glossary/workers-compensation-state-fund
} 
economy of the states' choice of benefits across time and place. Studies used measures of cash benefits to examine their influence on injury rates (Butler \& Worrall, 1983; Moore \& Viscusi, 1989, Krueger, 1990; Ruser, 1993; Guo \& Burton Jr, 2010). Similarly, a few papers looked at the effects of cash benefits on program costs and the estimated "benefit elasticity" of costs with respect to cash benefits (Krueger et al., 1990; Guo \& Burton Jr 2010). Overall, this strand of literature has focused on the period from the 1970s to the 1990s. One of our contributions is to update the estimate of the "benefit elasticity" using data of more recent time frame, from 1997 to 2016.

A smaller strand of literature developed measures that capture non-monetary eligibility requirements for injured workers to receive compensation benefits. Burton \& Spieler (2001) highlighted the legislative phenomenon initiated in the 1990s that tightened the eligibility requirements for workers' compensation benefits. A few studies documented significant impacts of imposing eligibility requirements on both workplace safety and cash benefits payment (Boden \& Ruser 2003; Guo \& Burton Jr 2010; Gentry \& Viscusi 2019). None of the studies to date have examined the structure of medical payments nor have they examined how specific procedural issues and burdens of proof might change the size of the benefits. What's more, prior work typically focused on eligibility laws that were passed in the 1980s and 1990s 6

One of our novel contribution comes from examining how benefit payments per covered worker in the states are influenced by laws related to burden of proof and proximate causes of injuries. Raising workers' burdens of proof is a more subtle procedural reform, instead of directly altering the amounts to be paid. Such procedural modifications can be a powerful channel affecting substantive outcomes. Congressional Representative John Dingell once said: "I'll let you write the substance...you let me write the procedure, and I'll screw you every time."'7 In a comprehensive treatise on workers' compensation, Spieler (2016) argues that "issues of proof" and the uses of legislative presumptions meant to streamline the administrative process have reduced worker access to benefits. The U.S. Department of Labor (undated, 17 and 22) shares the same concerns:

"Changes in the processing and adjudication of claims have had enormous, though perhaps more hidden, impact on injured workers' access

\footnotetext{
${ }^{6}$ The exception is Gentry \& Viscusi 2019) who used the Pro Publica index and developed two dummies which reflect whether workers' compensation programs become more generous or stringent. The dummy variables broadly include a wide range of eligibility rules that were passed in the recent two decades. The Pro Publica index only focuses on the changes in laws between 2002 and 2014 and does not include laws of the same type that were in place at the start of the period. We used the Pro Publica laws as a starting point and then did a comprehensive search of the workers' compensation laws already in place at the start of our time period and then went through the statutes that followed to double check the Pro Publica laws and to add any that they may have missed.

${ }^{7}$ Regulatory Reform Act: Hearing on H.R. 2327 Before the H. Subcomm. on Admin. Law and Governmental Relations, 98th Cong. 312 (1983)
} 
to benefits."

"New features of workers' compensation systems, such as higher burdens of proof for injured workers, serve to reduce access to benefits."

We assess how large an effect these changes in laws have had on changes in benefits per covered worker, both cash and medical.

Another contribution is our updating of the studies of the impact of medical-care restriction laws. Compared with injuries that occurred in non-work environments, the medical costs of treating work-related injuries are much higher (Durbin et al. 1996: Butler \& Worrall 1983). In response, states have been passing laws that restrict the use of medical care, such as imposing medical fee schedules and limiting workers' free choice of treating physicians. Earlier studies have examined the effects of medical-care restriction laws on work-related injuries and medical benefits payment but did not find evidence suggesting that the laws were effective (Boden \& Fleischman 1989, Pozzebon 1994; Boden \& Ruser 2003). None of the existing studies measured the impacts of medical-care restriction laws that were passed in the past two decades. Our research also fills this gap by assessing how cash and medical benefits are affected by medical fee schedule laws and physician network laws.

\section{Recent State Legislation}

\section{III.1 Overview}

Under the workers' compensation system, the burden of proof usually rests upon the injured worker to establish two types of causation: legal and medical. To establish legal causation, workers are usually required to make a prima facie showing all of the following three elements: (1) employees acted in the course of employment; (2) employees suffered an injury from an accident arising out of and in the course of employment; and (3) work activities contributed to the injury. To establish medical causation, workers are generally required to show that the accident caused the injury ${ }^{8}$ Usually, the evidentiary standard required to show causation is by the "preponderance of the evidence." If the worker fails to establish any of the three elements of causation, the benefits can be reduced or eliminated. Showing causation does not guarantee benefit payments. Employers could still avoid the payment by raising statutory defenses, such as intoxication and pre-existing conditions.

The workers' actual burdens are highly contextual and vary significantly based on the type of injury, the workers' characteristics, and the governing state law. The states have different presumptions of compensability, which affect the allocation of burdens of proof between employers and workers. For example, Maine case law

\footnotetext{
${ }^{8}$ The standard is elaborate in an Arizona Supreme Court decision, Grammatico v. Industrial Commission of Arizona, 117 P.3d 786. For detailed review of the decision, see Wheeler (2006).
} 
establishes a presumption that work injuries are not caused by diseases unrelated to employment. As a result, if employers attempt to escape compensation liability on the ground that the injuries are caused by prior diseases, they bear the burden to establish such a causal link ${ }^{9}$ What's more, the workers' burdens of proof could also change due to individual-specific characteristics, like the presence of a preexisting medical condition. An injured worker with a preexisting condition might have to show that the workplace accident was the major contributing cause of his injuries.

In examining the laws identified by Pro Publica and through our own reading of the statutes, we focus on five types of laws that influenced the likelihood of compensation or might reduce the amount of compensation on a proportional basis: (1) prohibitions on the use of the liberal construction rule; (2) presumption of workers' intoxication as the proximate cause of their injuries; (3) apportionment of benefits on the basis of workers' preexisting medical conditions; (4) the establishment of medical fee schedules; and (5) laws that initialize and regulate physician network to treat work-related injuries. Table 1 summarizes the states and times when each type of the laws was passed.

\section{III.2 Liberal Construction of Statutes}

Awards of benefits involve the interpretation of a variety of statutes. The "liberal construction rule" interprets the statute by presuming that workers prevail by default if there are ambiguities related to the merits of the claim. The countervailing doctrine is the "strict construction rule," which requires adjudicators to resolve disputes solely based on the evidentiary merits of the claims and opposes presuming either party as the default winner.

Statutes and case laws are the two main ways for states to adopt a liberal construction rule. Ohio and Maryland, for example, have explicit statutes that require the law to be liberally construed 10 The most commonly seen justification favoring the liberal construction rule is the remedial nature of workers compensation laws. For example, a Wisconsin decision held that a firefighter who died while saving his family from a fire at night was acting within the scope of employment; therefore, his family could receive workers' compensation death benefits. One justification for the ruling is that the remedial purpose of the law requires the statutory term, "within scope of employment," to be liberally interpreted to allow benefits payments 11

On the other hand, states prohibiting the liberal construction rule argue against the remedial nature of workers' compensation law. In those states, the goal of workers' compensation laws is to strike a balance between workers' interests in obtaining benefits and employers' interests in maintaining reasonably low costs of compensat-

\footnotetext{
${ }^{9}$ Davidson $v$. Bancroft, 560 A2d 13

${ }^{10}$ Ohio provision: R.C. $\S 4123.95$; Maryland provision: MD LABOR EMPLY § 9-102

${ }^{11}$ Town of Russell Volunteer Fire Dept. v. Labor and Industry Review Com'n, 223 Wis. 2d 723 (Ct. App. 1998)
} 
ing work injuries. Statutes in Florida ${ }^{12}$ and Minnesota 13 explicitly say that workers' compensation mutually renounces common law rights and defenses of workers and employers. Thus, the liberal construction rule is disallowed because it unjustifiably places workers' interests over employers' interests.

Prior to 1997, the beginning of our sample period, seven states prohibited the use of the liberal construction doctrine in resolving workers' compensation disputes. During our sample period from 1997 to 2016, four states passed new statutes prohibiting its use. A West Virginia amendment in 2003 stated:

"the Legislature hereby declares that any remedial component of the workers' compensation laws is not to cause the workers' compensation laws to receive liberal construction that alters in any way the proper weighing of evidence as required..."14

Similarly, Indiana legislation in 2006 implicitly prevented the adjudicator from making a presumption favorable to workers in issues related to burdens of proof 15

\section{III.3 Intoxication Presumed As a Proximate Cause of Injury}

In most of the states, intoxication is a statutory defense to reduce or eliminate compensation for an intoxicated worker injured on the job (Larson 1973). A worker's intoxication could significantly undermine the claim that the suffered injures were caused by the underlying risk of the employment. Whether intoxication is presumed to be the proximate cause of work-related injuries has significant implications for the workers' burdens of proof. If such presumption is not allowed, the employer bears the burden of establishing that intoxication was the proximate cause of the injury to avoid compensation liability. On the other hand, if such presumption is allowed, the injured worker bears the burden to show that their injuries are independent from the intoxication in order to receive compensation benefits. Allowing the presumption that intoxication is a proximate cause plausibly reduces the probability the injured worker will be compensated due to the added costs of collecting sufficient evidence to rebut the presumption.

A majority of the states disallow the presumption through common law precedents, statutes or a combination of both. The Minnesota workers' compensation statutes explicitly require employers to show intoxication is the proximate cause of workers' injuries ${ }^{16}$ A Virginia decision held that an injured worker, who suffered

\footnotetext{
${ }^{12}$ West's F.S.A. $\S$ 440.015: Legislative Intent

${ }^{13}$ M.S.A. $\S$ 176.001: Intent of the Legislature

${ }^{14} \mathrm{WV}$ ST $\S 23-1-1$

${ }^{15}$ IC 22-3-7-2: "The burden of proof is on the employee. The proof by the employee of an element of a claim does not create a presumption in favor of the employee with regard to another element of the claim."

${ }^{16}$ M.S.A. $§ 176.021$ :" If...the intoxication of the employee is the proximate cause of the injury, then the employer is not liable for compensation. The burden of proof of these facts is upon the employer."
} 
fractures due to a fall from a forklift pallet while clearly intoxicated, was still entitled to workers' compensation benefits 17 The ruling stated that the proximate cause of the injury was the backward movement of the forklift before lowering the pallet and the employer failed to establish that intoxication was the proximate cause of his injuries.

Prior to 1997, there were seven states that allowed the presumption of workers' intoxication as the proximate cause of injuries. During the sample period from 1997 to 2016, six additional states added new language allowing such a presumption. 18 The new language in Missouri in 2006 stated:

"The voluntary use of alcohol to the percentage of blood alcohol sufficient under Missouri law to constitute legal intoxication shall give rise to a rebuttable presumption that the voluntary use of alcohol under such circumstances was the proximate cause of the injury. A preponderance of the evidence standard shall apply to rebut such presumption."19

\section{III.4 Benefits Apportionment Due to Preexisting Conditions}

Preexisting conditions can potentially prevent injured workers from recovering the full amount of compensation benefits. Workers with preexisting health conditions are typically eligible for compensation benefits only if the job-related injuries significantly aggravate the intensity of the preexisting conditions. Injured workers are not eligible for compensation benefits if their symptoms are a "mere natural progression" of their preexisting conditions 20

Once "significant aggravation" of preexisting conditions is established, states have adopted one of two compensation regimes. About half of the states pay workers the full amount, which raises the financial burden on employers. To mitigate the financial burdens and to provide more employment opportunities to workers with preexisting conditions, some states have established "second injury funds" which partially cover compensation benefits payments to workers with preexisting conditions.

The rest of the states pay workers the fraction of benefits that matches the fraction of the condition that was solely induced by the workplace accident. These states usually only apportion permanent disability benefits. Workers can usually

\footnotetext{
${ }^{17}$ Wyle v. Professional Services Industries, Inc.,406 S.E.2d 410 (1991)

${ }^{18}$ Arziona(1999-2005), Texas(2005), Missouri(2006), Mississippi(2012) and Nevada(2015). In 1999, Arizona initiated the use of such presumption in A.R.S $\S$ 23-1021 (D) which was later struck down in 2005 by a state Supreme Court case, Grammatico v. Industrial Comm. The court held that such presumption violates workers' state constitutional right to compensation. Illinois is of its own category in the list.

${ }^{19}$ MO ST 287.120

${ }^{20}$ Bright v. Sheehan Pipeline, 960 P.2d 1009 (Wyo. 1998): Workers' injuries resulting from falling against a pipe is uncompensable because they are a natural and normal process of his preexisting conditions.
} 
recover the full amount of temporary disability benefits, regardless of the status of their preexisting conditions 21

To some extent the apportioning of benefits substantively relates directly to the amount of benefits paid. At the same time the apportionment also relates to burdens of proof because workers have to show that their medical symptoms are 100 percent attributable to the workplace accident in order to receive full benefits, and this often is difficult. Before 1997, there were 21 states with laws that apportioned benefits when workers had preexisting conditions. Over the sample period, three more states joined the benefits apportionment list.22 In California, the new language in 2004 read:

"(a)The employer shall only be liable for the percentage of permanent disability directly caused by the injury arising out of and occurring in the course of employment. (b)If the applicant has received a prior award of permanent disability, it shall be conclusively presumed that the prior permanent disability exists at the time of any subsequent industrial injury. This presumption is a presumption affecting the burden of proof.'23

\section{III.5 Medical-Care Restriction Laws}

The rapid increases in medical costs over the last 40 years have directly affected the medical costs of treating workplace injuries under workers' compensation. As a result, states have explored a variety of ways to control the costs while trying to maintain appropriate medical treatment of injuries. The two most common forms of medical legislation are laws that alter medical fee schedules and laws that establish state-wide networks of physicians to treat work-related injuries.

\section{III.5.1 Medical Fee Schedule Laws}

Adoption of a medical fee schedule puts a limit on the workers' compensation payment to medical care providers for providing injured workers with various medical services. The fee schedule is typically adopted by the state agency in charge of administering the workers' compensation program ${ }^{24}$

In states where the medical fee schedule system does not exist, there are other types of restrictions on medical benefit payments. Georgia state law requires the

\footnotetext{
${ }^{21}$ For example, the following is a Colorado statutory provision about benefits apportionment :" (3) An employee's temporary total disability, temporary partial disability, or medical benefits shall not be reduced based on a previous injury;(4) An employee's recovery of permanent total disability shall not be reduced ..." C.R.S.A Colo. Rev. Stat. Ann. § 8-42-104 (West)

${ }^{22}$ California(2004), Kansas(2011) and Missouri(2006)

${ }^{23}$ West's Ann.Cal.Labor Code $\S 4664$ (a) - (b)

${ }^{24}$ It's usually the commissioners of state workers' compensation commission. But there are exceptions. For example, in Oregon, it is the Director of Consumer and Business Service who is in charge of promulgating rules for developing and publishing fee schedules for medical services.
} 
State Board of Workers' Compensation to approve, on a case-by-case basis, the payment of physician fees, hospital charges, charges of prescription drugs or other costs of regulated medical items. All of the filed medical payments are reviewed on the "reasonablenes" standard by a panel of experts composed of peer physicians and hospital representatives 25

Prior to 1997, there were 24 states that had adopted fee schedule systems for medical service. During our sample period from 1997 to 2016, an additional 15 states adopted fee schedule provisions for medical service payments. For example, Idaho adopted a fee schedule in 2005 by adding the following language:

"The commission may adopt a fee schedule to determine the allowable payments to be made to medical providers under this chapter, including but not limited to, the fee schedule the commission has adopted to determine the allowable payments to be made to medical providers under the Idaho worker's compensation law."26

\section{III.5.2 Physician Choice and Physician Network Laws}

Choice of physicians is an important issue in the state workers' compensation programs. Employers and workers have competing self-interests in determining providers of medical care. Employers want to treat workers' injuries in a way that minimizes the medical costs. In contrast, if the medical services are covered, workers tend to have their injuries treated with the "best-quality" medical care and are less concerned about the costs. State laws developed various systems to account for the legitimate interests of both employers and workers.

In some states workers play a major role in determining medical care although their choices are usually subject to some restrictions ${ }^{27}$ In other states, medical care is mainly determined by employers. State laws usually require employers to furnish medical care and workers' choices are usually limited to what employers offer 28

Physician networks normally consist of doctors specialized in treating occupational diseases or general fields of medicine ${ }^{29}$ To join the network, medical care providers typically need to apply and get approved by the state agency in charge of administering the workers' compensation programs. Employers may choose to join the network for treating workers' work-related injuries, but this is not a mandate.

\footnotetext{
${ }^{25} \S 34-9-205(\mathrm{a})-(\mathrm{b})$

${ }^{26}$ ID ST $\S 72-1026$

${ }^{27}$ For example, in Hawaii, injured workers are free to choose any physician or surgeon who practice on the island. However, workers need to comply with fee schedules and provide sufficient notice to employers about the choice of physicians. See HI ST $\S 386-21$.

${ }^{28}$ In these states workers can only determine treating physicians under extraordinary circumstances, such as an emergency (See IN ST 22-3-3-4 and IA ST § 85.27) and an employers' failure to provide medical care (ID ST § 72-432).

${ }^{29}$ The physician network in California has the following website: https://www.dir.ca.gov/dwc/ mpn/dwc_mpn_faq.html
} 
If the employers are in the network, the physician choices of injured workers are constrained to choose a physician in the approved network.

Our analysis focuses on assessing the impacts of state laws that initiate and regulate physician networks to treat work-related injuries ${ }^{30}$ Prior to 1997, three states had authorized and regulated physician networks. Over our sample period from 1997 to 2016, four states passed new laws that established such networks. For example, California passed the following provision in 2005:

“... an insurer, employer, or entity that provides physician network services may establish or modify a medical provider network for the provision of medical treatment to injured employees. The network shall include physicians primarily engaged in the treatment of occupational injuries. The administrative director shall encourage the integration of occupational and nonoccupational providers ..., 31

\section{Data}

We construct a state-by-year panel dataset from 1997 to 2016 by putting together data from the National Academy of Social Insurance (NASI), Bureau of Labor Statistics (BLS), Social Security Administration (SSA), the ProPublica Website, and law volumes for the states.

\section{IV.1 Cash Benefits and Medical Benefits}

The dependent variables in the analysis are the cash benefits per covered worker and medical benefits per covered worker. The cash benefits are the payments to replace lost earnings for injured or deceased workplace accident victims. Covered workers refer to workers on employer payrolls who are eligible to receive benefits when injured. The information comes from annual NASI reports titled Workers' Compensation Benefits, Coverage, and Costs from 1997 through 2016 ${ }^{32}$ To obtain measures in 2010 U.S. dollars, we deflate the cash benefits by the national Consumer

\footnotetext{
${ }^{30}$ Private insurers also establish physician networks without the support of state regulation. For example, "Omnet Gold"(OG) is a physician network for work-related injuries in Louisiana and was developed entirely by a for-profit private insurer, Louisiana Workers' Compensation Corporation (LWCC), with little involvement from the state bureaucracy. Bernacki et al. (2006) performed a study that compared workers' compensation claims managed by the OG health-care providers to claims managed by non-OG healthcare providers with the following results: (1) the average number of reported lost days for closed OG claims is 53, lower than non-OG claims', 99; (2) the average medical care costs for closed OG claims is 5855, signicantly lower than non-OG claims', 9850 and (3) For closed OG claims, the average indemnity costs is 4864, lower than the non-OG claims', 7881.

${ }^{31} \mathrm{CA}$ LABOR $\S 4616$

${ }^{32}$ The reports can be downloaded from the following link: https://www.nasi.org/research/ workers-compensation
} 
Price Index for urban areas and medical benefits by the national Consumer Price Index for medical care 33 Figure 1 shows the trends of these calculations at the national level.

\section{IV.2 Workers' Compensation Expected Benefits Index}

To control for statutory changes in the payments for different types of accidents we follow Allen (2015) and Kantor \& Fishback (1995) in creating an "expected benefits index." The state laws generally stipulate different payment schemes for various accident outcomes. We divided injuries into four types: death, permanent total disability, permanent partial disability, and temporary total disability. With a few exceptions, the benefits payment schedules specify a weekly payment duration and a weekly payment amount that is a percentage of usual weekly earnings up to a weekly maximum and not below a weekly minimum. Most state laws index the weekly maximums to the annual state-level average weekly wage. Weekly cash benefits are determined by multiplying workers' weekly wage by a replacement percentage that is specified in statutes, usually $2 / 3$. The maximum weekly wage replacement data are collected from the Social Security Administration ${ }^{34}$ as well as state statutes.

For each accident type we calculate the present value of the stream of weekly payments using a discount rate of 5 percent and the national average weekly wage for that year ${ }^{35}$ We chose the national average weekly wage to ensure that the variation in the payments across states was driven only by statutory differences in the state laws. We then calculated real present values in 2010 dollars using the Consumer Price Index. Then, we calculated the weighted sum of the real present values of the four types of accident payments with the accident probabilities as weights ${ }^{36}$ The expected benefit index offers a single value for the generosity of workers' compensation cash benefits that incorporates information on the generosity for all types of accidents. We held the accident rate weights constant across time so that the only reasons for the changes in the state expected benefits is differences in statutes and changes over time in the national average wage. Figure 2 shows that the national average of these real expected benefit payments has a strong upward trend. To get the downward trend in national average cash payments per covered workers in Figure 1, there must be factors causing a strong downward trend that more than offset the rising trend in benefits.

\footnotetext{
${ }^{33}$ The Consumer Price Index data comes from the US Bureau of Labor Statistics and can be downloaded from the following website: https://www.bls.gov/cpi/data.htm

${ }^{34}$ The SSA maintains and regularly updates a chart of 'States' Maximum Workers' Compensation(WC) Benefits, which is publicly available and could be found from the following link: https://secure.ssa.gov/poms.nsf/lnx/0452150045

${ }^{5} \mathrm{SSA}$ develops a national average wage index for benefits computation purpose. Our national average wage is calculated by dividing the index by 52 . The index data can be found in the following website https://www.ssa.gov/oact/cola/AWI.html

${ }^{36}$ The accident probability data comes from Accident Facts, which was published by the National Safety Council in 1997.
} 


\section{IV.3 Fatal Accident Rate}

One of the factors that has contributed to the decline in benefit payments per covered worker in Figure 1 is the improvement of workplace safety, reflected by a decline in accident rate. Information by state and year for the number of fatal accidents and the number employed in private industry come from the Bureau of Labor Statistics (BLS) ${ }^{37}$ We then calculate the number of fatal workplace accidents per 100,000 workers in private industry for each year and state. Fatal injury information is available in all of the states as reporting of workplace fatal injuries is mandatory. But non-fatal injury information is only available in states that are willing participate BLS Survey of Occupational Injuries and Illness, which is not federally mandated. Due to substantial number of missing value issue for the non-fatal injury data, we chose to use fatal injury data as the proxy of workplace safety environment. The national average of the fatal accident rate in Figure 3 fell by about one-third between 1997 and 2016. This decline is potentially a reason for the declines in benefits per covered worker seen in Figure 1. The national average for missed days due to nonfatal injuries in the reporting states also showed a significant decline over the study period.

\section{IV.4 State Laws}

The set of state laws collected by Pro Publica inspired our interest in studying the issue, but Grabell and Qiu only collected new state laws between 2002 and 2014 38 We expanded on their work by using the statute volumes for the states from WestLaw to establish the status quo as of 1997 and to add laws passed in other years through 2016. For each of the category of laws, we created dummy variables with a value of one if the law was present in the state and zero otherwise ${ }^{39}$ As shown in the discussion of the state laws, some had versions of a law throughout the time period, others added the law during the time frame and others did not. Table 1 summarizes the states and years when each types of laws were passed.

\footnotetext{
${ }^{37}$ BLS maintains and regularly updates data on state-level occupational injuries, illness and fatalities. The data can be access using the following link: https://www.bls.gov/iif/state_archive .htm\#AZ The employment data come from the Current Employment Statistics (CES) in BLS. The data are the seasonally adjusted number of employment in private industry at given state and year. The data can be assessed from the following link: https://www.bls.gov/data/\#employment

${ }^{38}$ Their full study is in the following link: https://projects.propublica.org/graphics/ workers-comp-reform-by-state

${ }^{39}$ We dropped Oklahoma in the empirical analysis due to unique and significant changes to the state workers' compensation system, which are hard to quantify. In 2013, a new law allowed employers to opt-out of the the state workers' compensation system, which was struck down as unconstitutional in a 2016 Oklahoma State Supreme Court decision. See Vasquez v. Dillard's Inc., 381 P.3d 768 (2016). NPR has extensive media coverage of the Oklahoma decision, refer to the following link: https://www.npr.org/2016/09/13/493805684/oklahomas-top-court-says -companies-cant-set-own-rules-for-injured-workers
} 


\section{Econometric Models}

Our goal is to examine how the laws influence the total benefits paid out per covered worker, which is essentially every worker in the sectors covered by the workers' compensation law. Thus, covered workers include the non-injured, the injured who receive benefits, and the injured who do not receive benefits. Scholars and practitioners predict that each of the five laws would reduce average benefits per covered worker because fewer injured workers would obtain benefits or the benefits that they receive would be reduced. There is a possibility that a change in the burden of proof might lead to an increase in the average benefits paid per claim to injured workers who actually receive benefits because of increases in "case quality." This would happen if some injured workers stop pursuing claims altogether because the costs of meeting the burden of proof are too high when there is a dispute 40 Average benefits per covered worker would still fall when the fall in the number of injured workers receiving benefits and the increase in the number of workers who accept lower benefits in dispute settlements is large enough to offset the case quality effect. The final effect of all three possible changes is an empirical question that the econometric analysis directly addresses.

To estimate the relationships between average benefits per covered worker and the laws, we employ the following fixed effects model as the main specification:

$$
\begin{aligned}
\text { Log Benefits }_{s t} & =\beta_{0}+\beta_{1} \log \text { Index }_{s t}+\beta_{2} \text { Log Fatal Accident Rate } \\
& +\beta_{3} \text { Legislation }_{s t}+\delta_{s}+\tau_{t}+\theta_{s} t+\varepsilon_{s t}
\end{aligned}
$$

The outcome variable is $\log$ Benefit $_{s t}$, the natural logarithm of benefit payments per covered worker, either cash or medical, in state $s$ at year $t$. Log Index st is the natural logarithm of workers' compensation expected benefits index in state $s$ at year $t$. The expected benefits index variable is only included for analyzing cash benefits, as it does not capture any information related to medical benefits payments. Log Accident Rate $_{s t}$ is the natural logarithm of fatal accident rate in state $s$ year $t$.

Legislation $_{\text {st }}$ is a vector that includes dummy variables for the 5 different types of state laws. Each dummy has a value of one if the law is in place and zero otherwise. Thus, states with the relevant law as of 1997 have a value of one throughout the time period. Once a state passes the law the dummy has a value of one thereafter.

\footnotetext{
${ }^{40}$ The issue of increased case quality through selection arose in empirical studies evaluating the causal impact of the heightened pleading standard introduced by Bell Atlantic v. Twombly, 550 U.S. 544 (2007) and Ashcroft v. Iqbal, 129 S.Ct. 1937 (2009). Twombly and Iqbal replaced the previous "no-set-of-fact" pleading standard with a new "plausibility" standard, which raised the evidentiary bar for litigated cases to survive a motion to dismiss. In empirical studies the new standard had little impact on the probability of granting motions to dismiss (Hubbard 2013, 2017) or of surviving summary judgment (Gelbach, 2016). Gelbach (2011) developed an economic model that outlines the channels through which higher quality cases are selected into litigation through decisions by defendants and plaintiffs in the settlement process.
} 
$\delta_{s}$ is a vector of state fixed effects, controlling for time-invariant and state-specific unobserved characteristics, such as workers' demographics and industry composition. $\tau_{t}$ is a vector of year fixed effects, accounting for national shocks like changes in federal OSHA regulations. We also include a vector of state-specific time trends, $\theta_{s} t$, to account for state-specific trends. It is necessary to include a state-specific time trend in the main specification to avoid spurious correlation because both cash and medical benefits per covered worker tended to have downward trends. Standard errors are clustered at the state level (Bertrand et al., 2004).

The variation used to estimate the relationships comes from deviations from trend over time within the same state after controlling for national shocks. For the law coefficients to be causal estimates, the law dummies must be uncorrelated with the error term, $\varepsilon_{s t}$, after controlling for the expected benefits index, the fatal accident rate, time-invariant features of the states, trends in the states, and national shocks. If there is endogeneity bias based on reverse causation related to the political economy of the laws, we anticipate in each case that it will be positive. States are more likely to adopt measures to limit benefits of both kinds in settings where benefits are high and rising faster than anticipated. If this prediction holds, the coefficient estimates would understate the impact of the laws on benefit payments per covered worker.

To test the strength of our identification, we implement the following lead-lag placebo test, which imposes a slight modification to the main model :

$$
\begin{aligned}
& \text { Log Benefits } \text { Bt }=\beta_{0}+\beta_{1} \log \text { Index }_{s t}+\beta_{2} \text { Log Fatal Accident Rate } \text { St }_{\text {I }} \\
& +\gamma_{i} \text { Legislation }_{s t+i}+\delta_{s}+\tau_{t}+\theta_{s} t+\varepsilon_{s t}
\end{aligned}
$$

Compared with Model(1), Model(2) adds leads or lags to the dummies in the Legislation $_{s t}$ vector. $i$ index the lags or leads and take integer values from -3 to 3. For example, if $i$ is -2 , the Legislation coefficient measures the relationships between benefits and the law while pretending the law had been adopted 2 years prior to the actual year of adoption. If there is no selection bias associated with the state adopting the law, the coefficient $\gamma_{i}$ will be statistically indistinguishable from zero. Similarly, if $i$ is 3 , the coefficient measures the impact by pretending the passage of the law was delayed by 3 years. The estimates in the $\gamma_{i}$ then tell us whether the legislative effects are contemporaneous or are delayed over time. We performed separate placebo tests one by one for leads of $-3,-2$ and -1 years and lags of 1,2 and 3 years.

\section{Main Results}

Our main results are based on regression specifications that include all five types of the laws, which are reported in Tables 2 and 3 . In addition, we also separately estimate the effects of each type of law, which are reported in the Appendix. 
Table 2 shows the OLS estimates of how cash benefits payments are affected by various workers' compensation laws. The preferred specification is in Column (4) which includes state fixed effects, year fixed effects and state-specific linear time trend. The results suggest that cash benefits payments are lower in states that adopted these types of laws. The cash benefits are 9.8 percent lower in states that prohibit the use of the literal construction rule, 11.7 percent lower in states with intoxication laws, 17 percent lower in states where benefits can be apportioned based on workers' preexisting conditions, 2.5 percent lower in states that adopted medical fee schedules and 15.3 percent lower in states with physician network laws. All of law coefficients are statistically significant except the one for medical fee schedules.

Another key finding is that there is a strong relationship between the cash benefits payment and expected benefits index. As both the payment and the index are in natural logarithm forms, the estimated coefficient is the elasticity of actual benefit payments per covered worker with respect to statutory benefits, which is similar to the "benefit elasticity" in the literature. The results suggest that a 1 percent increase in the expected benefits index is associated with a 1.15 percent increase in the cash benefits payment. The estimated elasticity is slightly larger than 1 and consistent with the estimate by Krueger et al. (1990) where they found an one unit increase in workers' compensation benefits is approximately associated with an one unit increase of employers' costs in paying workers' compensation claims. Finally, although we expected a positive coefficient for the fatal accident rate, the elasticity is very small at -0.007 and statistically insignificant.

Our main goal is to try to describe which changes are most closely related to the decline in the national average of cash benefits per covered worker between 1997 and 2016. Using the means for the variables for 1997 and 2016 and the coefficients, we developed a decomposition to see how much weight to give to the laws (Oaxaca \& Ransom 1994). Table 4 shows the results of decomposition analysis for cash benefit payments. The mean of the natural log of cash benefits per worker fell from 5.38 in 1997 to 5.01 in 2016 . While the mean of the log of expected benefits rose, the $\log$ of the fatal accident rate fell, and the share of states with each of the laws rose. After multiplying by the coefficients in Column (4) of Table 2, the decomposition shows that the rise in the log expected benefit measure was associated with raising the $\log$ benefit per covered worker by $53.2 \%$. The drop in the log fatal accident rate explains very little. The new laws banning liberal construction accounted for $2.1 \%$ of the national drop, the ones for intoxication accounted for $2.5 \%$ of the drop, the apportionment laws for prior conditions accounted for $1.9 \%$ of the drop, the physician network laws accounted for 3.3\% of the drop and the preexisting condition laws accounted for $0.9 \%$ of the drop. In total, the five types of workers' compensation laws can explain $10.7 \%$ of the declines of the national average of cash benefits payments per covered worker.

Table 3 shows the OLS estimates of how medical benefits are affected by the workers' compensation laws. Again, Column (4) is the preferred specification. The 
results show the medical benefits per covered worker were significantly lower in states that adopted each type of the law. They are $4.4 \%$ lower in states that banned liberal constructions, $8 \%$ lower in states with new intoxication legislation, $19 \%$ lower in states that apportioned benefits based on preexisting conditions, $1.6 \%$ lower in states that adopted medical fee schedule laws and $20 \%$ lower in states that adopted physician network laws. The point estimate for medical fee schedule laws is the only one that is not statistically significant. This set of results is consistent with our finding in cash benefits payment, suggesting the laws negatively affected both cash and medical benefits payments in similar ways. The result for medical fee schedule laws is consistent with Pozzebon (1994), who did not find evidence that having medical fee schedule is negatively correlated with medical benefits payment. It is plausible that states, without formal medical fee schedules, might have other types of restrictions on reimbursement of medical care expenses, such as some form of administrative review. In addition, as expected, the fatal injury rate is positively correlated with medical benefits payment, but the coefficient of 0.02 is relatively small and statistically indistinguishable from 0.

Again, using the means for the variables in 1997 and 2016 and the coefficients, we developed an another decomposition analysis to see how much of the decline in the national medical benefits payment per covered worker can be explained by the passage of workers' compensation laws. The results are in Table 5. The mean of the natural $\log$ of the medical benefits per covered worker fell from 5.41 in 1997 to 5.13 in 2016. Using the estimated coefficients in Column (4) of Table 3 , our decomposition exercise suggests that the laws banning liberal construction can explain $1.2 \%$ of the drop in the national medical benefits payment, the intoxication laws can explain $2.1 \%$ of the drop, laws allowing benefits apportionment due to preexisting conditions can explain $2.7 \%$ of the drop, medical fee schedule laws can explain $0.7 \%$ of the drop and physician network laws can explain $6.5 \%$ of the drop. In total, the new workers' compensation laws can explain $13.3 \%$ of the declines in the national average of medical benefits payment per covered worker.

\section{Placebo Test Results}

To further investigate the strength of the identification, we perform a series of placebo tests by estimating Equation (2). To perform the tests, we generate a series of "placebo" laws by shifting the timing of the laws forward and backward by one year, two year and three years. Statistically insignificant effects of the "placebo" laws provide additional support that the coefficients on cash and medical benefits payments are driven by the changes of workers' compensation laws, instead of unobserved underlying trends. However, it is also plausible that the "placebo" laws could yield statistically significant effects. For example, if impacts of the laws are persistent or the implementation of the laws takes time, we should see significant "placebo" effects in the regressions where the timing of the laws are lagged. Sim- 
ilarly, if people started responding the laws earlier in anticipation that the laws would pass in the future, we should see statistically significant "placebo" effects in regressions where we add leads to the timings of the laws. Table 6 and Table 7 show the placebo tests results on the effects of workers' compensation laws on cash and medical benefit payments respectively. The column labeled "No Change" in Table 6 shows the estimates for the actual timing of the laws from column (4) in Table 2. while the "No Change" column in Table 7 shows the estimates for the actual timing from column (4) in Table 3.

For the laws that prohibit liberal construction, the first row of Table 6 shows no sign that the negative relationship between the eventual adoption of the law and benefits per covered worker was present prior to its actual implementation. When the placebo law is introduced three years early, two years early, or one year early, the coefficient is positive, the opposite sign, and statistically insignificant. When we artificially delay the law by one, two, or three years, the effects of the law become more negative, which suggests that it might have taken some time before the negative effects were fully manifested. The results for medical benefits per covered worker in Table 6 also show statistically insignificant effects when we artificially move the passage of the law earlier in time. When we delay the law artificially, the coefficients of the delayed laws are more negative than under the "No Change" column but they are not statistically significant.

The placebo test results for apportionment laws also show no sign that there was a negative relationship of cash benefits per covered worker prior to the adoption of the laws. When we set the placebo laws earlier in Table 6, two of the three coefficients are positive, the opposite sign, and the coefficient for the one-year lead is much smaller than the actual law coefficient and not statistically significant. When we push the timing of the law later than the true timing, the coefficients become somewhat more negative. The results are similar in Table 7 for medical benefits per covered worker with the exception that artificially delaying the laws by two or three years leads to less negative coefficients.

The results in Tables 6 and 7 for the intoxication laws raise some questions about the negative impact we found for the actual timing of the laws in Tables 2 and 3 . When we artificially move the laws earlier in Table 6, the coefficients are negative and statistically significant and of similar size to the -0.116 coefficient for the actual timing of the law. Similarly, pushing the law forward for medical benefits per covered worker in Table 7 leads to a negative and statistically significant coefficient of -0.0942 for the artificial law one year earlier that is larger than the -0.0758 coefficient for the actual timing.

There is some question raised about the negative effects of the physician network laws as well in Tables 6 and 7. The results follow a similar pattern as for the intoxication laws. In both Tables 6 and 7 there is at least one coefficient for an artificially early law that is statistically significant and roughly the same size as the coefficient for the actual timing of law. 
The results for the placebo tests for the medical fee schedule laws in Tables 6 and 7 are essentially the same as the results in Tables 2 and 3 . The coefficients are small and statistically insignificant in all but one case.

The results of the placebo tests show that we can comfortably make claims that the bans on liberal construction and the apportionment of benefits based on preceding conditions contributed to a drop in both average cash benefits and average medical benefits per covered worker. Although we found negative relationships found for the intoxication law and the physician network law, the presence of lower benefits prior to the eventual adoption of the law leaves uncertainty about their ultimate impact.

\section{Conclusion}

Over the past two decades most states have amended their workers' compensation laws and the national average of benefits per covered worker have fallen sharply for both cash and medical benefits. These trends raised concerns that workers were receiving less from the Grand Bargain associated with the laws. We show here that statutory benefits have actually risen during this time frame, pushing workers' compensation payments in the opposite direction. So what has been driving payments per covered worker down?

We provide a partial answer to the puzzle by empirically investigating how benefit payments are influenced by state laws that make it more difficult to obtain benefits based on burden of proof and by controlling access to expensive medical treatments. We examine the impact of five types of laws: prohibit the use of liberal construction rules, assume intoxication as the proximate cause of work-related injuries, apportion benefits on the basis of preexisting condi-tions, impose medical fee schedules, and establish state-wide physician networks to treat work-related injuries.

The two laws that had negative effects that survive placebo tests are the laws that ban liberal construction rules and that apportion benefits based on pre-existing conditions. In the states where they were enacted, the bans on liberal construction rules was associated with a drop of 9.8 percent in cash benefits per covered worker and 4.4 percent in medical benefits per covered workers. The percentage drops associated with the apportionment laws in the states where they were adopted were 17 and 19 percent, respectively. The results show that changes in burden of proof can have substantial impact on the payments to workers' compensation.

One goal of the paper has been to examine how much of the change in national average benefits per covered worker between 1997 and 2016 in Figures 1 can be attributed to these laws. These are large drops in the states involved, but their impact on the national averages were smaller because only four states adopted the liberal construction ban and three adopted apportionment between 1997 and 2016 (Table 1). The bans on liberal construction contributed 2.1 percent and apportion-

ment laws contributed 1.8 percent of the drop in national average cash benefits per 
covered workers in Figure 1, while they contributed 1.2 percent and 2.7 percent of the drop in the national medical benefits in Figure1.

\section{References}

Allen, S. K. (2015). Struggle for regulatory power between states and the us federal government: The case of workers compensation insurance 1930-2000. Journal of Economics and Political Economy, 2(3), 351-373.

Bernacki, E. J., Tao, X. G., \& Yuspeh, L. (2006). An investigation of the effects of a healthcare provider network on costs and lost time in workers' compensation. Journal of occupational and environmental medicine, 48(9), 873-882.

Bertrand, M., Duflo, E., \& Mullainathan, S. (2004). How much should we trust differences-in-differences estimates? The Quarterly Journal of Economics, $119(1), 249-275$.

Boden, L. I., \& Fleischman, C. A. (1989). Medical costs in workers' compensation: trends and interstate comparisons. Workers Compensation Research Institute.

Boden, L. I., \& Ruser, J. W. (2003). Workers' compensation "reforms," choice of medical care provider, and reported workplace injuries. Review of Economics and Statistics, 85(4), 923-929.

Burton, F., \& Spieler, E. (2001). Workers' compensation and older workers.

Butler, R. J., \& Worrall, J. D. (1983). Workers' compensation: Benefit and injury claims rates in the seventies. The Review of Economics and Statistics, 580-589.

Durbin, D. L., Corro, D., \& Helvacian, N. (1996). Workers' compensation medical expenditures: Price vs. quantity. Journal of Risk and Insurance, 13-33.

Fishback, P. V. (2016). Long-term trends related to the grand bargain of workers' compensation. Rutgers UL Rev., 69, 1185.

Fishback, P. V., \& Kantor, S. E. (1995). Did workers pay for the passage of workers' compensation laws? The Quarterly Journal of Economics, 110(3), 713-742.

Fishback, P. V., \& Kantor, S. E. (1998). The adoption of workers' compensation in the united states, 1900-1930. The Journal of Law and Economics, 41(2), $305-342$.

Gelbach, J. B. (2011). Locking the door to discovery-assessing the effects of twombly and iqbal on access to discovery. Yale LJ, 121, 2270.

Gelbach, J. B. (2016). Material facts in the debate over twombly and iqbal. Stan. L. Rev., 68, 369 . 
Gentry, E., \& Viscusi, K. (2019, 07). Asymmetric effects on fatality rates of changes in workers' compensation laws. American Law and Economics Review. Retrieved from https://doi.org/10.1093/aler/ahz007 (ahz007) doi: 10.1093/aler/ ahz007

Guo, X., \& Burton Jr, J. F. (2010). Workers' compensation: Recent developments in moral hazard and benefit payments. ILR Review, 63(2), 340-355.

Hubbard, W. H. (2013). Testing for change in procedural standards, with application to bell atlantic v. twombly. The Journal of Legal Studies, 42(1), 35-68.

Hubbard, W. H. (2017). The effects of twombly and iqbal. Journal of Empirical Legal Studies, 14(3), 474-526.

Kantor, S. E., \& Fishback, P. V. (1995). Nonfatal accident compensation and the common law at the turn of the century. JL Econ. E Org., 11, 406.

Krueger, A. B. (1990). Incentive effects of workers' compensation insurance. Journal of Public Economics, 41(1), 73-99.

Krueger, A. B., Burton Jr, J. F., et al. (1990). The employers' costs of workers' compensation insurance: Magnitudes, determinants, and public policy. The Review of Economics and Statistics, 72(2), 228-240.

Larson, A. (1973). Intoxication as a defense in workmen's compensation. Cornell L. Rev., 59, 398 .

McLaren, C. F., \& Baldwin, M. L. (2016). Workers' compensation: Benefits, coverage, and costs,(2015 data). National Academy of Social Insurance: Washington, $D C$.

Moore, M. J., \& Viscusi, W. K. (1989). Promoting safety through workers' compensation: The efficacy and net wage costs of injury insurance. The RAND Journal of Economics, 499-515.

Morantz, A., Bodson, J., Levine, S. M., \& Palsson, M. V. (2016). Economic incentives in workers' compensation: A holistic, international perspective. Rutgers UL Rev., 69, 1015.

Oaxaca, R. L., \& Ransom, M. R. (1994). On discrimination and the decomposition of wage differentials. Journal of Econometrics, 61(1), 5-21.

Pozzebon, S. (1994). Medical cost containment under workers' compensation. ILR Review, 48(1), 153-167.

Relkin, E. (2016). The demise of the grand bargain: Compensation for injured workers in the 21st century. Rutgers UL Rev., 69, 881. 
Ruser, J. W. (1993). Workers' compensation and the distribution of occupational injuries. Journal of Human Resources, 28(3).

Spieler, E. A. (2016). (re) assessing the grand bargain: Compensation for work injuries in the united states, 1900-2017. Rutgers UL Rev., 69, 891.

Wheeler, T. M. (2006). Grammatico v. industrial commission: Invalidating statutes making alcohol or drug use a bar to workers' compensation claims in arizona. Ariz. L. Rev., 48, 211.

Williams, R. F. (2016). Can state constitutions block the workers' compensation race to the bottom. Rutgers UL Rev., 69, 1081. 


\section{Figures and Tables}

Figure 1: National Cash and Medical Benefit Payments Per Covered Workers in 2010 Dollars

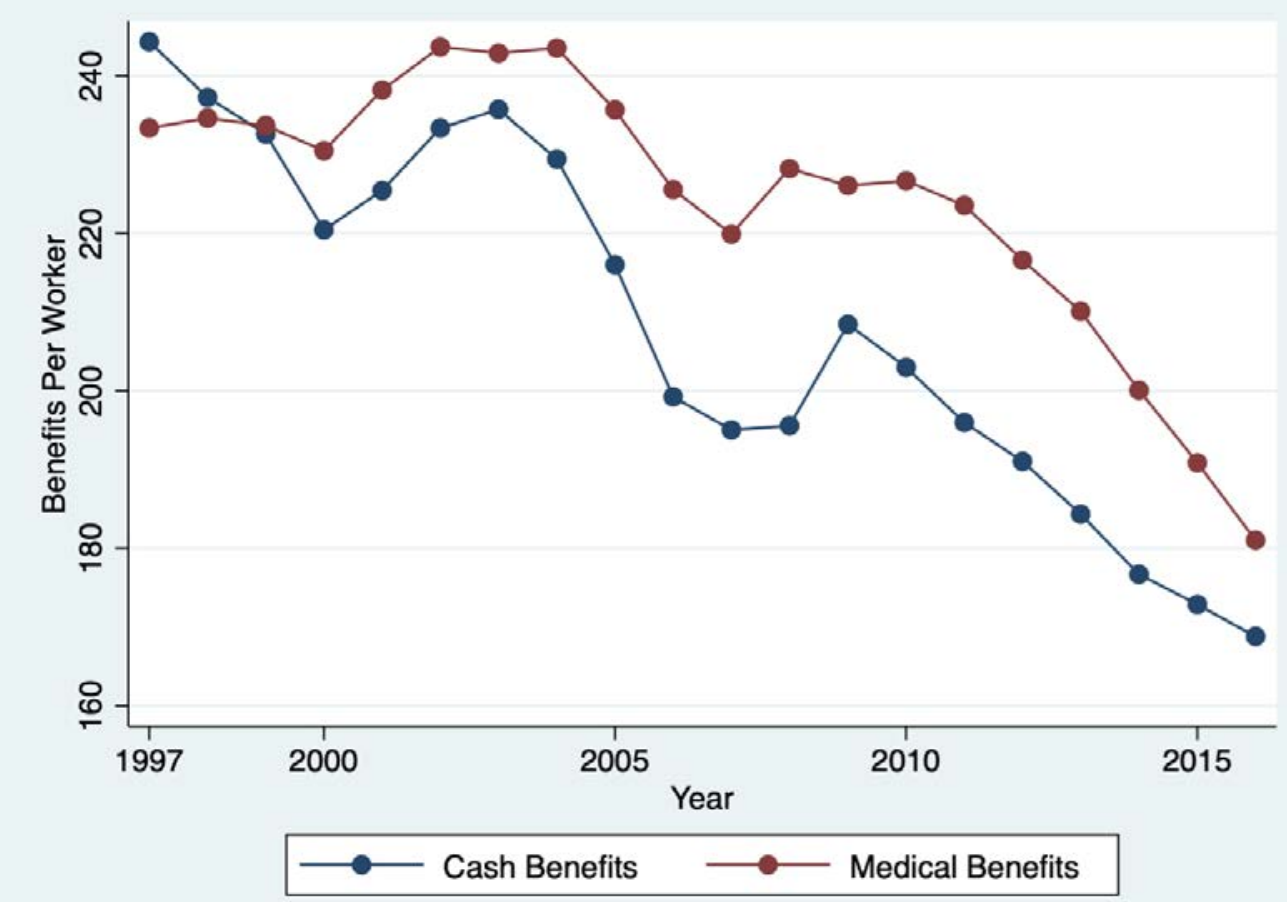

Source: State-by-year level data of cash benefit payments, medical benefit payments and the number of covered workers come from the annual workers' compensation reports issued by National Academy of Social Insurance (NASI). The nominal cash benefits are deflated by the urban Consumer Price Index (CPI) and the medical benefits are deflated by the medical Consumer Price Index collected from Bureau of Labor Statistics (BLS). 
Figure 2: National Workers' Compensation Expected Caah Benefits Index in 2010 Dollars

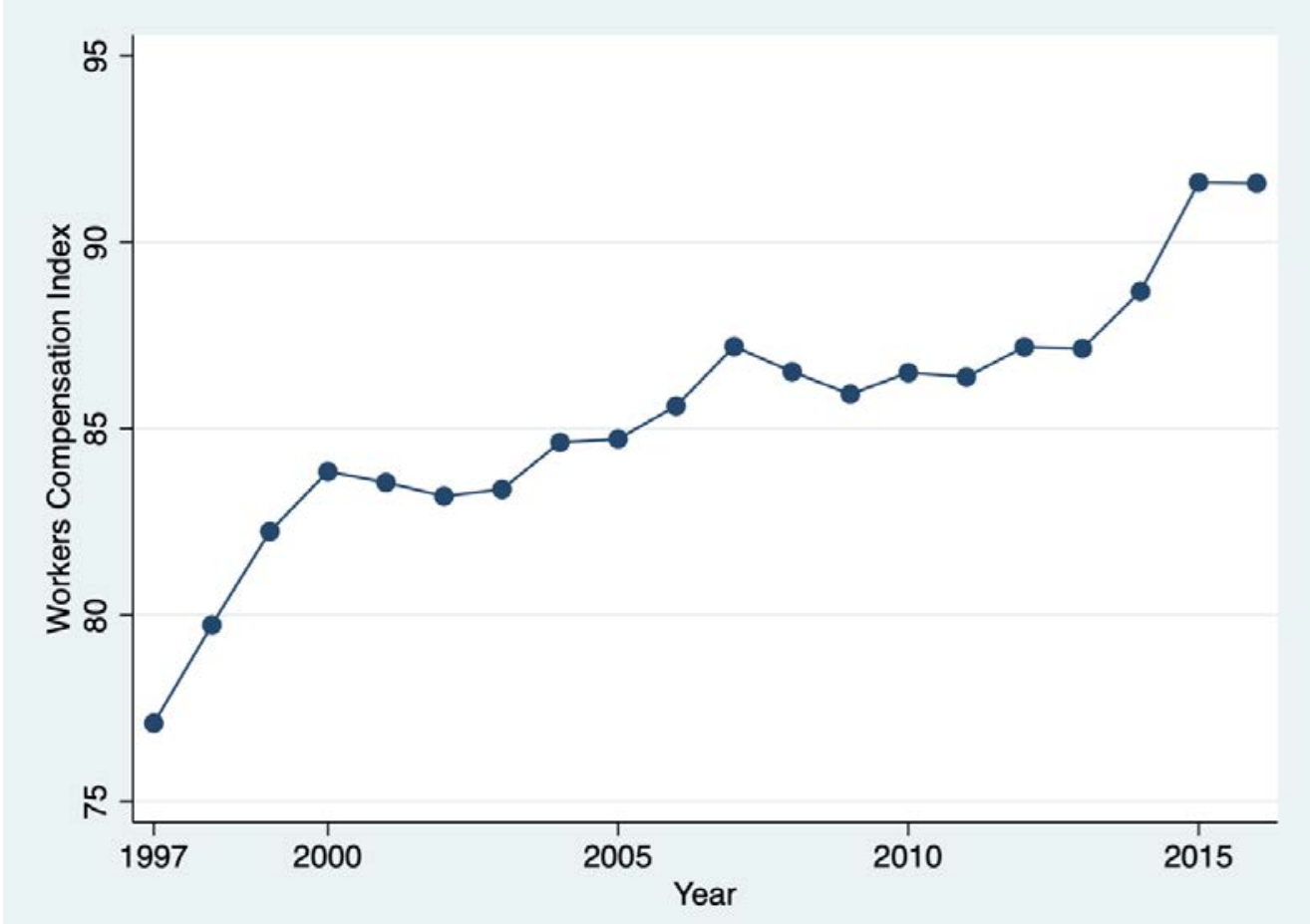

Source: State-level weekly maximum benefits and national level average wage index data come from Social Security Administration (SSA). The nominal benefits are deflated by CPI data from BLS. 
Figure 3: National Fatal Accident Rate

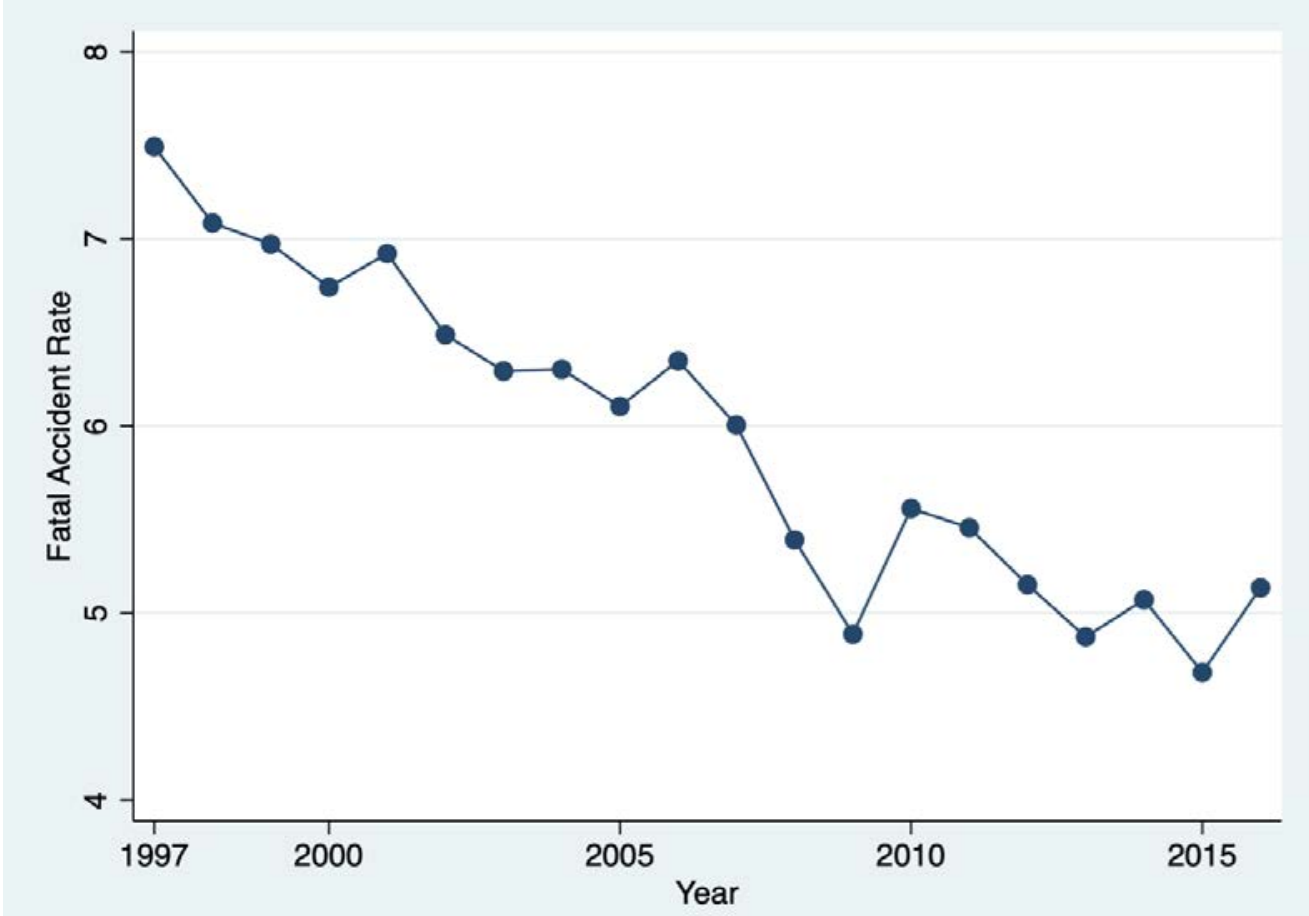

Source: Fatal accident rate is defined as the number of fatal accidents per 100,000 workers in private industry. The measure is calculated with the following two strands of state-level data from BLS: seasonally adjusted employment and total counts of reported occupational fatalities. 


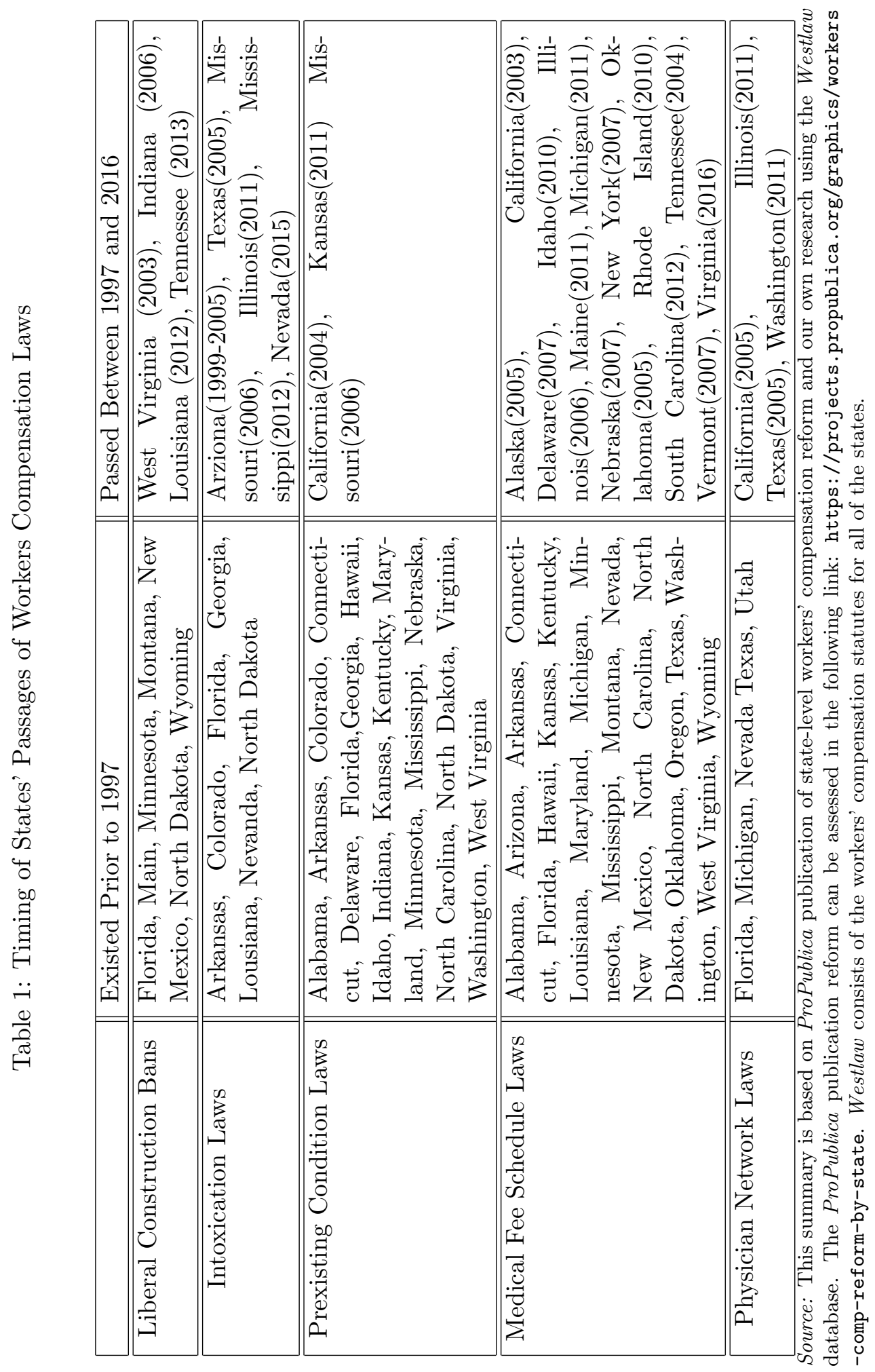


Table 2: The Effects of Workers' Compensation Laws on Cash Benefit Payments Per Covered Worker When All Laws Are Included in Specification

\begin{tabular}{lcccc}
\hline \hline & $(1)$ & $(2)$ & $(3)$ & $(4)$ \\
\hline Expected Benefits Index (log) & -0.0897 & $-1.347^{* * *}$ & $1.693^{* * *}$ & $1.139^{* * *}$ \\
& $(0.520)$ & $(0.371)$ & $(0.422)$ & $(0.225)$ \\
Fatal Injury Rate (log) & -0.154 & $0.0599^{*}$ & -0.00968 & -0.00785 \\
& $(0.104)$ & $(0.0344)$ & $(0.0416)$ & $(0.0211)$ \\
Liberal Construction Ban & 0.0522 & $-0.330^{* *}$ & $-0.239^{*}$ & $-0.0963^{*}$ \\
& $(0.150)$ & $(0.151)$ & $(0.120)$ & $(0.0535)$ \\
Intoxication Laws & & & & \\
& $-0.240^{*}$ & $-0.195^{* *}$ & -0.134 & $-0.116^{* *}$ \\
Apportionment Laws & $(0.142)$ & $(0.0801)$ & $(0.0952)$ & $(0.0443)$ \\
& -0.0377 & $-0.137^{*}$ & -0.136 & $-0.178^{*}$ \\
Medical Fee Schedule Laws & $(0.130)$ & $(0.0707)$ & $(0.0815)$ & $(0.0969)$ \\
& 0.136 & 0.0229 & 0.0803 & -0.0129 \\
Physician Network Laws & $(0.130)$ & $(0.0570)$ & $(0.0554)$ & $(0.0408)$ \\
& -0.205 & -0.121 & -0.0618 & $-0.152^{* * *}$ \\
& $(0.225)$ & $(0.0925)$ & $(0.107)$ & $(0.0483)$ \\
\hline State Fixed Effects & & $\mathrm{X}$ & $\mathrm{X}$ & $\mathrm{X}$ \\
Year Fixed Effects & & & $\mathrm{X}$ & $\mathrm{X}$ \\
State-specific Time Trend & & & $\mathrm{X}$ \\
$R^{2}$ & 0.097 & 0.280 & 0.429 & 0.765 \\
$N$ & 1000 & 1000 & 1000 & 1000 \\
\hline \hline
\end{tabular}

Note: Standard errors are in parenthesis and clustered at state level. Significance Levels: ${ }^{*} p<0.1,{ }^{* *} p<0.05,{ }^{* * *} p<0.01$ 
Table 3: The Effects of Workers' Compensation Laws on Medical Benefit Payments Per Covered Worker When All Laws Are Include in Specification

\begin{tabular}{lcccc}
\hline \hline & $(1)$ & $(2)$ & $(3)$ & $(4)$ \\
\hline Fatal Injury Rate $(\log )$ & $0.219^{* * *}$ & $0.107^{* * *}$ & 0.00136 & 0.0199 \\
& $(0.0758)$ & $(0.0387)$ & $(0.0347)$ & $(0.0215)$ \\
Liberal Construction Ban & 0.0985 & $-0.201^{* * *}$ & $-0.0963^{* *}$ & $-0.0429^{*}$ \\
& $(0.0908)$ & $(0.0338)$ & $(0.0443)$ & $(0.0250)$ \\
Intoxication Laws & $-0.197^{* *}$ & $-0.258^{* *}$ & $-0.217^{* *}$ & $-0.0758^{* *}$ \\
& $(0.0857)$ & $(0.0968)$ & $(0.0810)$ & $(0.0352)$ \\
Apportionment Laws & 0.0432 & 0.0762 & 0.0645 & $-0.191^{* * *}$ \\
& $(0.0724)$ & $(0.0821)$ & $(0.0643)$ & $(0.0373)$ \\
Medical Fee Schedule Laws & 0.0511 & 0.00166 & $0.0828^{*}$ & -0.00832 \\
& $(0.0674)$ & $(0.0435)$ & $(0.0423)$ & $(0.0269)$ \\
Physician Network Laws & -0.0322 & $-0.283^{* * *}$ & $-0.210^{* * *}$ & $-0.233^{* * *}$ \\
& $(0.163)$ & $(0.0675)$ & $(0.0723)$ & $(0.0456)$ \\
\hline State Fixed Effects & & $\mathrm{X}$ & $\mathrm{X}$ & $\mathrm{X}$ \\
Year Fixed Effects & & & $\mathrm{X}$ & $\mathrm{X}$ \\
State-specific Time Trend & & & $\mathrm{X}$ \\
$R^{2}$ & 0.194 & 0.193 & 0.390 & 0.659 \\
$N$ & 1000 & 1000 & 1000 & 1000 \\
\hline \hline
\end{tabular}

Note: Standard errors are in parenthesis and clustered at state level. Significance Levels: ${ }^{*} p<0.1,{ }^{* *} p<0.05,{ }^{* * *} p<0.01$ 


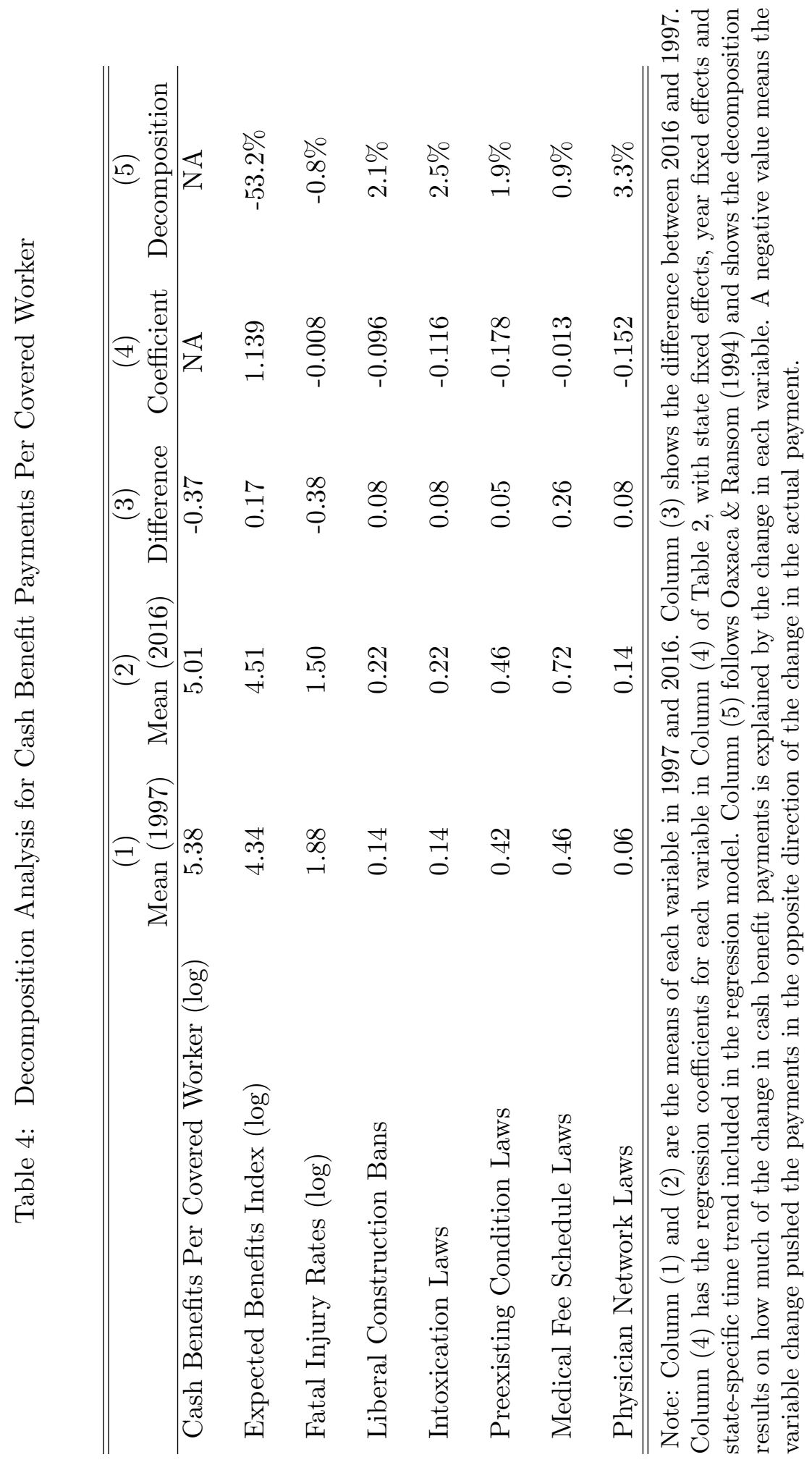




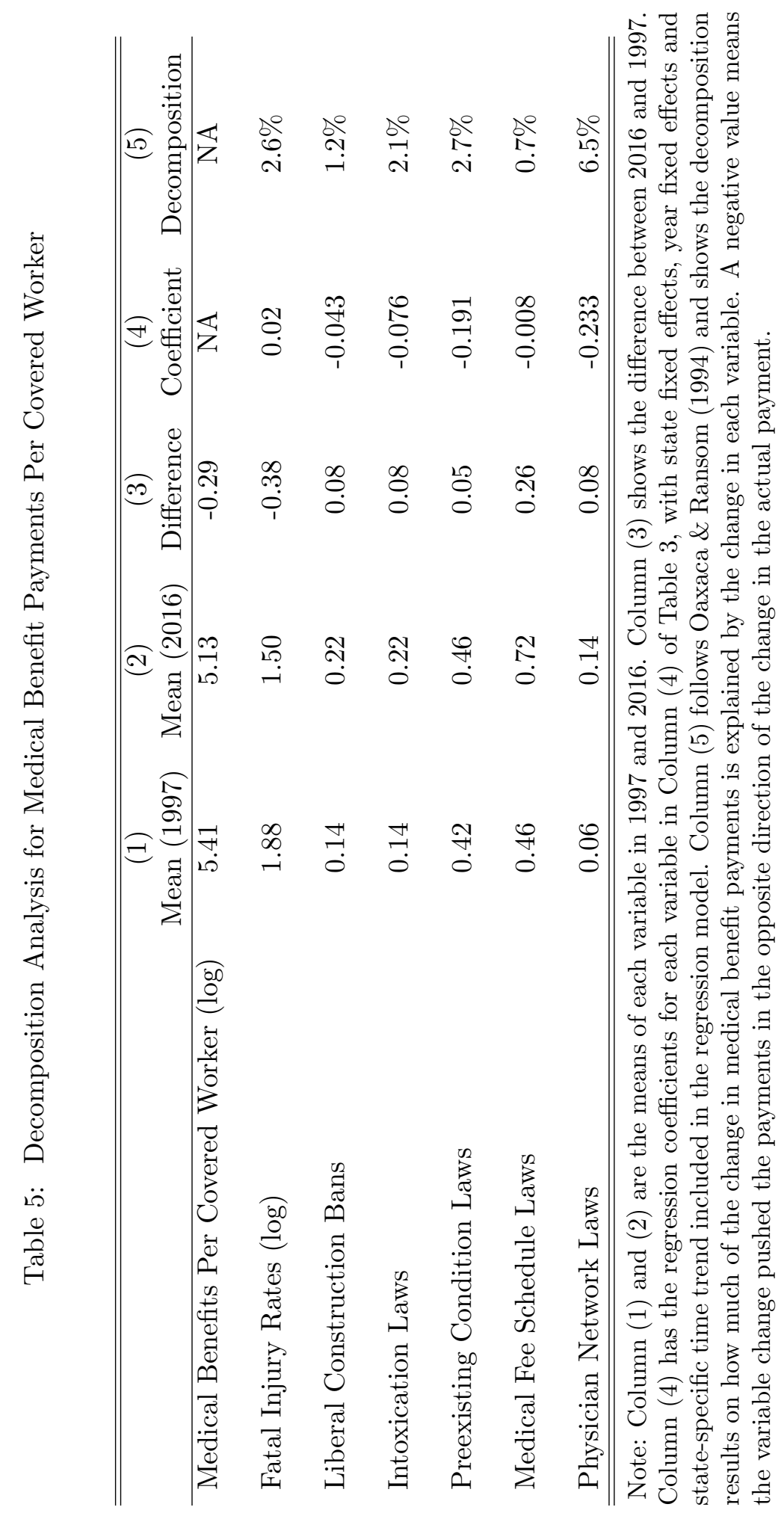




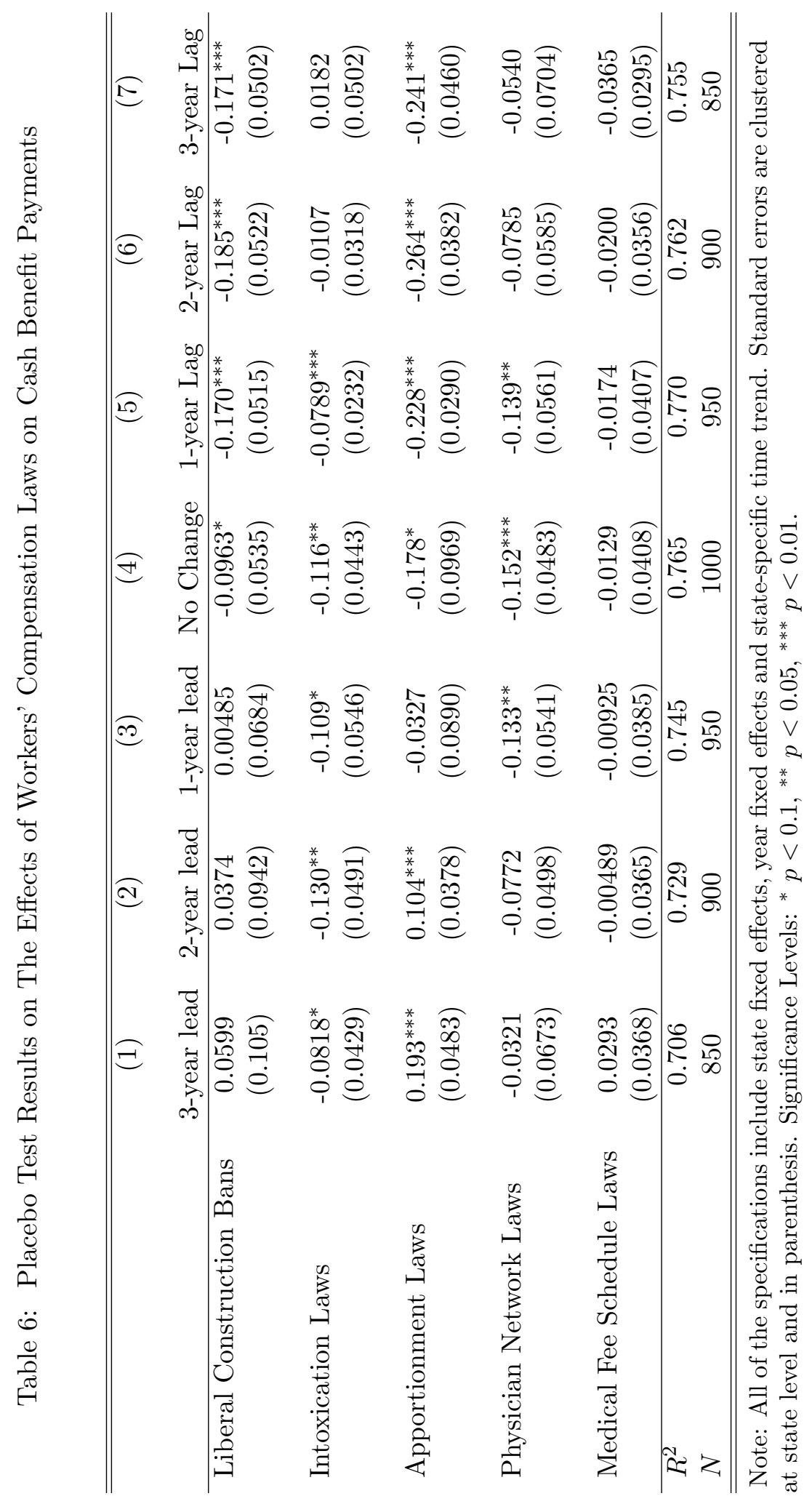




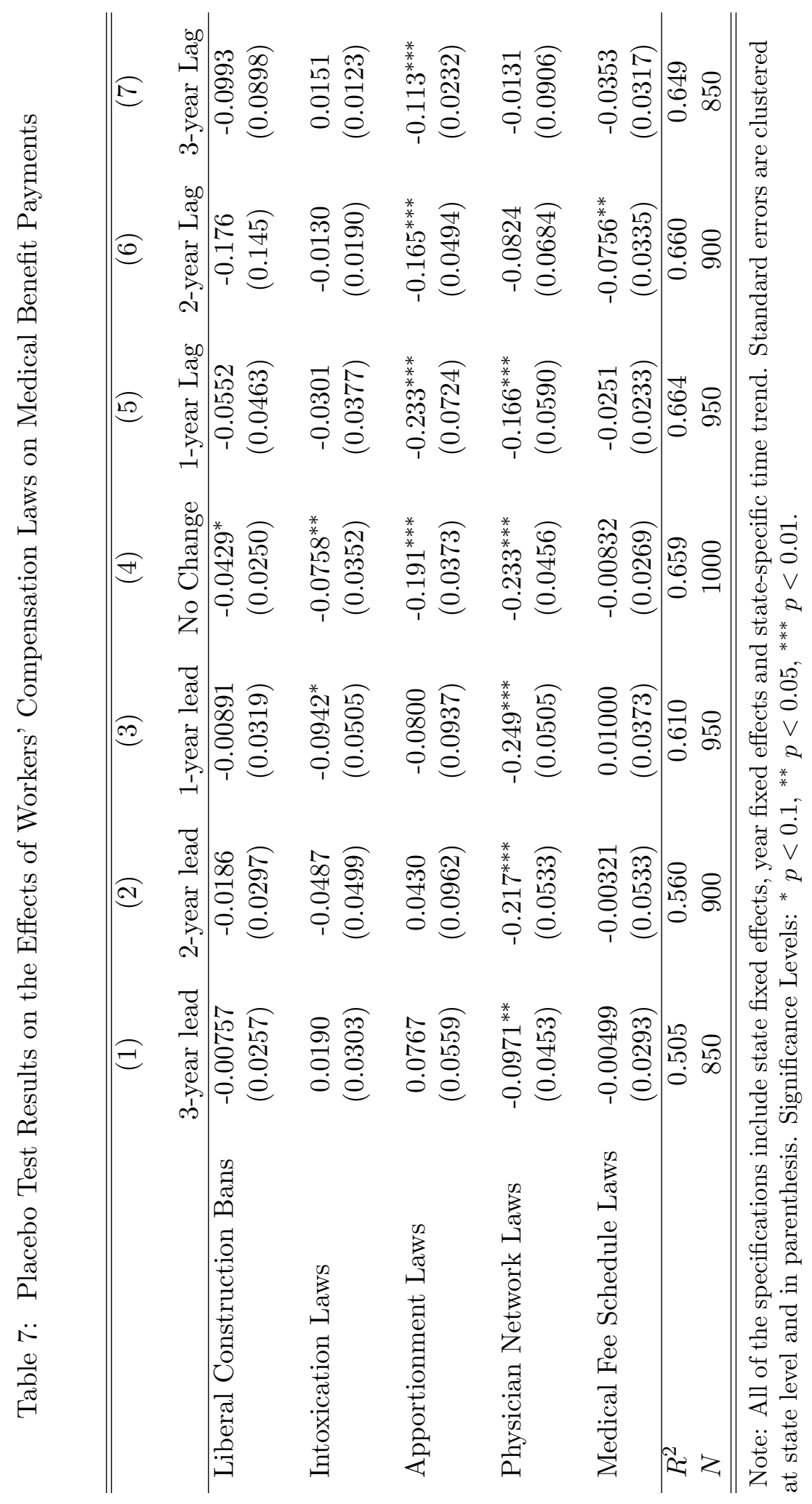




\section{Appendix}

\section{A Additional Results on the Effects of Each Type of the Laws}

This Appendix reports the more detailed results on how cash and medical benefit payments are affected by each of the five different types of law we empirically examine. For each type of the laws, we show the results of its effects on cash and medical benefit payments across different regression models with state fixed effects, year fixed effects and state-specific time trend. Overall, the results are fairly robust across various specifications.

\section{A.1 Laws Prohibiting Liberal Construction Rule}

Table 1: The Effects of Liberal Construction Bans on Cash Benefits Payments

\begin{tabular}{lcccc}
\hline \hline & $(1)$ & $(2)$ & $(3)$ & $(4)$ \\
\hline Expected Benefits Index (log) & 0.122 & $-1.442^{* * *}$ & $1.842^{* * *}$ & $1.160^{* * *}$ \\
& $(0.482)$ & $(0.398)$ & $(0.423)$ & $(0.219)$ \\
& & & & \\
Fatal Injury Rates (log) & -0.144 & $0.0677^{*}$ & -0.0160 & -0.00953 \\
& $(0.104)$ & $(0.0381)$ & $(0.0466)$ & $(0.0213)$ \\
Liberal Construction Bans & 0.0595 & $-0.321^{* *}$ & $-0.233^{*}$ & $-0.0922^{*}$ \\
& $(0.137)$ & $(0.152)$ & $(0.116)$ & $(0.0541)$ \\
\hline State Fixed Effects & & $\mathrm{X}$ & $\mathrm{X}$ & $\mathrm{X}$ \\
Year Fixed Effects & & & $\mathrm{X}$ & $\mathrm{X}$ \\
State-specific Time Trend & & & & $\mathrm{X}$ \\
$R^{2}$ & 0.026 & 0.231 & 0.397 & 0.752 \\
$N$ & 1000 & 1000 & 1000 & 1000 \\
\hline \hline
\end{tabular}

Note: Standard errors are in parenthesis and clustered at state level. Significance Levels: ${ }^{*} p<0.1,{ }^{* *} p<0.05,{ }^{* * *} p<0.01$ 
Table 2: The Effects of Liberal Construction Ban on Medical Benefits Payment

\begin{tabular}{lcccc}
\hline \hline & $(1)$ & $(2)$ & $(3)$ & $(4)$ \\
\hline Fatal Injury Rates $(\log )$ & $0.211^{* *}$ & $0.132^{* * *}$ & -0.00725 & 0.0195 \\
& $(0.0809)$ & $(0.0439)$ & $(0.0416)$ & $(0.0220)$ \\
Liberal Construction Bans & 0.101 & $-0.197^{* * *}$ & $-0.0854^{*}$ & -0.0389 \\
& $(0.0832)$ & $(0.0340)$ & $(0.0428)$ & $(0.0263)$ \\
\hline State Fixed Effects & & $\mathrm{X}$ & $\mathrm{X}$ & $\mathrm{X}$ \\
Year Fixed Effects & & & $\mathrm{X}$ & $\mathrm{X}$ \\
State-specific Time Trend & & & & $\mathrm{X}$ \\
$R^{2}$ & 0.143 & 0.073 & 0.306 & 0.636 \\
$N$ & 1000 & 1000 & 1000 & 1000 \\
\hline \hline
\end{tabular}

Note: Standard errors are in parenthesis and clustered at state level. Significance Levels: ${ }^{*} p<0.1,{ }^{* *} p<0.05,{ }^{* * *} p<0.01$ 


\section{A.2 Laws Presuming Intoxication as the Proximate Cause of In- juries}

Table 3: The Effects of Intoxication Laws on Cash Benefits Payment

\begin{tabular}{lcccc}
\hline \hline & $(1)$ & $(2)$ & $(3)$ & $(4)$ \\
\hline Expected Benefits Index (log) & 0.0950 & $-1.536^{* * *}$ & $1.784^{* * *}$ & $1.127^{* * *}$ \\
& $(0.427)$ & $(0.370)$ & $(0.544)$ & $(0.217)$ \\
& & & & \\
Fatal Injury Rates (log) & -0.104 & $0.0659^{*}$ & -0.0197 & -0.00741 \\
& $(0.0962)$ & $(0.0379)$ & $(0.0483)$ & $(0.0216)$ \\
& & & & \\
Intoxication Laws & $-0.254^{*}$ & $-0.256^{* * *}$ & $-0.183^{*}$ & $-0.164^{* *}$ \\
& $(0.128)$ & $(0.0945)$ & $(0.100)$ & $(0.0737)$ \\
\hline State Fixed Effects & & $\mathrm{X}$ & $\mathrm{X}$ & $\mathrm{X}$ \\
Year Fixed Effects & & & $\mathrm{X}$ & $\mathrm{X}$ \\
State-specific Time Trend & & & & $\mathrm{X}$ \\
$R^{2}$ & 0.063 & 0.217 & 0.390 & 0.756 \\
$N$ & 1000 & 1000 & 1000 & 1000 \\
\hline \hline
\end{tabular}

Note: Standard errors are in parenthesis and clustered at state level. Significance Levels:

${ }^{*} p<0.1,{ }^{* *} p<0.05,{ }^{* * *} p<0.01$

Table 4: The Effects of Intoxication Laws on Medical Benefits Payment

\begin{tabular}{lcccc}
\hline \hline & $(1)$ & $(2)$ & $(3)$ & $(4)$ \\
\hline Fatal Injury Rates (log) & $0.251^{* * *}$ & $0.131^{* * *}$ & -0.00630 & 0.0212 \\
& $(0.0754)$ & $(0.0430)$ & $(0.0406)$ & $(0.0221)$ \\
& & & & \\
Intoxication Laws & $-0.178^{*}$ & $-0.303^{* *}$ & $-0.250^{* *}$ & $-0.135^{* *}$ \\
& $(0.0947)$ & $(0.135)$ & $(0.118)$ & $(0.0665)$ \\
\hline State Fixed Effects & & $\mathrm{X}$ & $\mathrm{X}$ & $\mathrm{X}$ \\
Year Fixed Effects & & & $\mathrm{X}$ & $\mathrm{X}$ \\
State-specific Time Trend & & & & $\mathrm{X}$ \\
$R^{2}$ & 0.169 & 0.116 & 0.347 & 0.641 \\
$N$ & 1000 & 1000 & 1000 & 1000 \\
\hline \hline
\end{tabular}

Note: Standard errors are in parenthesis and clustered at state level. Significance Levels:

${ }^{*} p<0.1,{ }^{* *} p<0.05,{ }^{* * *} p<0.01$ 


\section{A.3 Benefits Apportionment Laws Due to Preexisting Conditions}

Table 5: The Effects of Apportionment Laws on Cash Benefits

\begin{tabular}{lcccc}
\hline \hline & $(1)$ & $(2)$ & $(3)$ & $(4)$ \\
\hline Expected Benefits Index (log) & 0.129 & $-1.537^{* * *}$ & $1.874^{* * *}$ & $1.196^{* * *}$ \\
& $(0.460)$ & $(0.406)$ & $(0.499)$ & $(0.216)$ \\
& & & & \\
Fatal Injury Rates (log) & -0.129 & 0.0616 & -0.0245 & -0.00983 \\
& $(0.100)$ & $(0.0373)$ & $(0.0483)$ & $(0.0213)$ \\
& & & & \\
Apportionment Laws & -0.0323 & $-0.267^{* * *}$ & $-0.195^{* * *}$ & $-0.265^{* *}$ \\
& $(0.126)$ & $(0.0565)$ & $(0.0547)$ & $(0.111)$ \\
\hline State Fixed Effects & & $\mathrm{X}$ & $\mathrm{X}$ & $\mathrm{X}$ \\
Year Fixed Effects & & & $\mathrm{X}$ & $\mathrm{X}$ \\
State-specific Time Trend & & & & $\mathrm{X}$ \\
$R^{2}$ & 0.025 & 0.202 & 0.382 & 0.756 \\
$N$ & 1000 & 1000 & 1000 & 1000 \\
\hline \hline
\end{tabular}

Note: Standard errors are in parenthesis and clustered at state level. Significance Levels:

${ }^{*} p<0.1,{ }^{* *} p<0.05,{ }^{* * *} p<0.01$

Table 6: The Effects of Apportionment Laws on Medical Benefits

\begin{tabular}{lcccc}
\hline \hline & $(1)$ & $(2)$ & $(3)$ & $(4)$ \\
\hline Fatal Injury Rates (log) & $0.228^{* * *}$ & $0.133^{* * *}$ & -0.0107 & 0.0194 \\
& $(0.0804)$ & $(0.0443)$ & $(0.0416)$ & $(0.0217)$ \\
Apportionment Laws & 0.0288 & $-0.165^{* *}$ & $-0.0980^{*}$ & $-0.270^{* * *}$ \\
& $(0.0766)$ & $(0.0642)$ & $(0.0561)$ & $(0.0305)$ \\
\hline State Fixed Effects & & $\mathrm{X}$ & $\mathrm{X}$ & $\mathrm{X}$ \\
Year Fixed Effects & & & $\mathrm{X}$ & $\mathrm{X}$ \\
State-specific Time Trend & & & & $\mathrm{X}$ \\
$R^{2}$ & 0.134 & 0.058 & 0.305 & 0.644 \\
$N$ & 1000 & 1000 & 1000 & 1000 \\
\hline \hline
\end{tabular}

Note: Standard errors are in parenthesis and clustered at state level. Significance Levels:

${ }^{*} p<0.1,{ }^{* *} p<0.05,{ }^{* * *} p<0.01$ 


\section{A.4 Medical Fee Schedule Laws}

Table 7: The Effects of Medical Fee Schedule Laws on Cash Benefits Payments

\begin{tabular}{lcccc}
\hline \hline & $(1)$ & $(2)$ & $(3)$ & $(4)$ \\
\hline Expected Benefits Index (log) & 0.0730 & $-1.611^{* * *}$ & $1.902^{* * *}$ & $1.189^{* * *}$ \\
& $(0.505)$ & $(0.409)$ & $(0.476)$ & $(0.219)$ \\
& & & & \\
Fatal Injury Rates (log) & -0.151 & $0.0716^{* *}$ & -0.0152 & -0.00906 \\
& $(0.102)$ & $(0.0351)$ & $(0.0447)$ & $(0.0215)$ \\
Medical Fee Schedule Laws & 0.112 & 0.0129 & 0.0823 & -0.0135 \\
& $(0.118)$ & $(0.0572)$ & $(0.0564)$ & $(0.0429)$ \\
\hline State Fixed Effects & & $\mathrm{X}$ & $\mathrm{X}$ & $\mathrm{X}$ \\
Year Fixed Effects & & & $\mathrm{X}$ & $\mathrm{X}$ \\
State-specific Time Trend & & & & $\mathrm{X}$ \\
$R^{2}$ & 0.037 & 0.183 & 0.381 & 0.751 \\
$N$ & 1000 & 1000 & 1000 & 1000 \\
\hline \hline
\end{tabular}

Note: Standard errors are in parenthesis and clustered at state level. Significance Levels:

${ }^{*} p<0.1,{ }^{* *} p<0.05,{ }^{* * *} p<0.01$

Table 8: The Effects of Medical Fee Schedule Laws on Medical Benefits Payments

\section{$(1)$}

$(2)$

$(3)$

$(4)$

\begin{tabular}{lcccc}
\hline Fatal Injury Rates (log) & $0.220^{* * *}$ & $0.136^{* * *}$ & -0.00236 & 0.0199 \\
& $(0.0761)$ & $(0.0422)$ & $(0.0368)$ & $(0.0218)$ \\
Medical Fee Schedule Laws & 0.0634 & -0.0175 & $0.0856^{* *}$ & -0.00931 \\
& $(0.0673)$ & $(0.0407)$ & $(0.0422)$ & $(0.0275)$ \\
\hline State Fixed Effects & & $\mathrm{X}$ & $\mathrm{X}$ & $\mathrm{X}$ \\
Year Fixed Effects & & & $\mathrm{X}$ & $\mathrm{X}$ \\
State-specific Time Trend & & & & $\mathrm{X}$ \\
$R^{2}$ & 0.140 & 0.048 & 0.315 & 0.636 \\
$N$ & 1000 & 1000 & 1000 & 1000 \\
\hline \hline
\end{tabular}

Note: Standard errors are in parenthesis and clustered at state level. Significance Levels:

${ }^{*} p<0.1,{ }^{* *} p<0.05,{ }^{* * *} p<0.01$ 


\section{A.5 Physician Network Laws}

Table 9: The Effects of Physician Network Laws on Cash Benefits Payment

\begin{tabular}{lcccc}
\hline \hline & $(1)$ & $(2)$ & $(3)$ & $(4)$ \\
\hline Expected Benefits Index (log) & 0.0894 & $-1.514^{* * *}$ & $1.891^{* * *}$ & $1.186^{* * *}$ \\
& $(0.477)$ & $(0.397)$ & $(0.504)$ & $(0.207)$ \\
& & & & \\
Fatal Injury Rates (log) & -0.153 & 0.0624 & -0.0230 & -0.0108 \\
& $(0.104)$ & $(0.0381)$ & $(0.0485)$ & $(0.0215)$ \\
Physician Network Laws & -0.242 & -0.183 & -0.0953 & $-0.181^{* * *}$ \\
& $(0.220)$ & $(0.123)$ & $(0.132)$ & $(0.0573)$ \\
\hline State Fixed Effects & & $\mathrm{X}$ & $\mathrm{X}$ & $\mathrm{X}$ \\
Year Fixed Effects & & & $\mathrm{X}$ & $\mathrm{X}$ \\
State-specific Time Trend & & & & $\mathrm{X}$ \\
$R^{2}$ & 0.045 & 0.199 & 0.376 & 0.756 \\
$N$ & 1000 & 1000 & 1000 & 1000 \\
\hline \hline
\end{tabular}

Note: Standard errors are in parenthesis and clustered at state level. Significance Levels: ${ }^{*} p<0.1,{ }^{* *} p<0.05,{ }^{* * *} p<0.01$

Table 10: The Effects of Physician Network Laws on Medical Benefits Payment

\begin{tabular}{lcccc}
\hline \hline & $(1)$ & $(2)$ & $(3)$ & $(4)$ \\
\hline Fatal Injury Rates (log) & $0.225^{* * *}$ & $0.116^{* * *}$ & -0.0117 & 0.0181 \\
& $(0.0798)$ & $(0.0427)$ & $(0.0405)$ & $(0.0215)$ \\
Physician Network Laws & -0.0638 & $-0.328^{* *}$ & $-0.230^{*}$ & $-0.258^{* * *}$ \\
& $(0.176)$ & $(0.131)$ & $(0.132)$ & $(0.0497)$ \\
\hline State Fixed Effects & & $\mathrm{X}$ & $\mathrm{X}$ & $\mathrm{X}$ \\
Year Fixed Effects & & & $\mathrm{X}$ & $\mathrm{X}$ \\
State-specific Time Trend & & & & $\mathrm{X}$ \\
$R^{2}$ & 0.135 & 0.124 & 0.337 & 0.651 \\
$N$ & 1000 & 1000 & 1000 & 1000 \\
\hline \hline
\end{tabular}

Note: Standard errors are in parenthesis and clustered at state level. Significance Levels: ${ }^{*} p<0.1,{ }^{* *} p<0.05,{ }^{* * *} p<0.01$ 